\title{
Sedimentology and Provenance of the
}

Early Proterozoic Michigamme Formation and Goodrich Quartzite, Northern MichiganRegional Stratigraphic Implications and Suggested Correlations

\section{U.S. GEOLOGICAL SURVEY BULLETIN 1904-R}

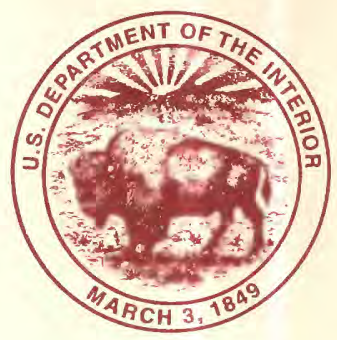




\section{AVAILABILITY OF BOOKS AND MAPS OF THE U.S. GEOLOGICAL SURVEY}

Instructions on ordering publications of the U.S. Geological Survey, along with prices of the last offerings, are given in the current-year issues of the monthly catalog "New Publications of the U.S. Geological Survey." Prices of available U.S. Geological Survey publications released prior to the current year are listed in the most recent annual "Price and Availability List." Publications that may be listed in various U.S. Geological Survey catalogs (see back inside cover) but not listed in the most recent annual "Price and Availability List" may no longer be available.

Reports released through the NTIS may be obtained by writing to the National Technical Information Service, U.S. Department of Commerce, Springfield, VA 22161; please include NTIS report number with inquiry.

Order U.S. Geological Survey publications by mail or over the counter from the offices listed below.

\section{BY MAIL}

\section{Books}

Professional Papers, Bulletins, Water-Supply Papers, Techniques of Water-Resources Investigations, Circulars, publications of general interest (such as leaflets, pamphlets, booklets), single copies of Earthquakes \& Volcanoes, Preliminary Determination of Epicenters, and some miscellaneous reports, including some of the foregoing series that have gone out of print at the Superintendent of Documents, are obtainable by mail from

\section{U.S. Geological Survey, Map Distribution Box 25286, MS 306, Federal Center Denver, CO 80225}

Subscriptions to periodicals (Earthquakes \& Volcanoes and Preliminary Determination of Epicenters) can be obtained ONLY from the

\section{Superintendent of Documents \\ Government Printing Office Washington, DC 20402}

(Check or money order must be payable to Superintendent of Documents.)

\section{Maps}

For maps, address mail orders to

\section{U. S. Geological Survey, Map Distribution Box 25286, Bldg. 810, Federal Center Denver, CO 80225}

Residents of Alaska may order maps from

$$
\begin{aligned}
& \text { U.S. Geological Survey, Earth Science Information Center } \\
& \text { 101 Twelfth Ave., Box } 12 \\
& \text { Fairbanks, AK } 99701
\end{aligned}
$$

\section{OVER THE COUNTER}

\section{Books and Maps}

Books and maps of the U.S. Geological Survey are available over the counter at the following U.S. Geological Survey offices, all of which are authorized agents of the Superintendent of Documents.

- ANCHORAGE, Alaska-Rm. 101, 4230 University Dr.

- LAKEWOOD, Colorado-Federal Center, Bldg. 810

- MENLO PARK, California-Bldg. 3, Rm. 3128, 345 Middlefield Rd.

- RESTON, Virginia-USGS National Center, Rm. 1C402, 12201 Sunrise Valley Dr.

- SALT LAKE CITY, Utah-Federal BIdg., Rm. 8105, 125 South State St.

- SPOKANE, Washington-U.S. Post Office Bldg., Rm. 135, West 904 Riverside Ave.

- WASHINGTON, D.C.-Main Interior Bldg., Rm. 2650, 18th and C Sts., NW.

\section{Maps Only}

Maps may be purchased over the counter at the following

U.S. Geological Survey offices:

- FAIRBANKS, Alaska-New Federal Bldg, 101 Twelfth Ave.

- ROLLA, Missouri-1400 Independence Rd.

- STENNIS SPACE CENTER, Mississippi-Bldg. 3101 
Chapter R

Sedimentology and Provenance of the Early Proterozoic Michigamme Formation and Goodrich Quartzite, Northern MichiganRegional Stratigraphic Implications and Suggested Correlations

By RICHARD W. OJAKANGAS

U.S. GEOLOGICAL SURVEY BULLETIN 1904

CONTRIBUTIONS TO PRECAMBRIAN GEOLOGY OF LAKE SUPERIOR REGION P.K. SIMS and L.M.H. CARTER, Editors 


\title{
U.S. DEPARTMENT OF THE INTERIOR BRUCE BABBITT, Secretary
}

\author{
U.S. GEOLOGICAL SURVEY
}

Gordon P. Eaton, Director

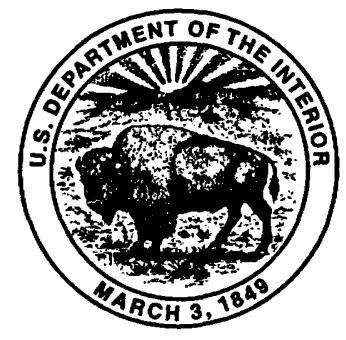

Any use of trade, product, or firm names in this publication is for descriptive purposes only and does not imply endorsement by the U. S. Government.

\section{UNITED STATES GOVERNMENT PRINTING OFFICE: 1994}

For sale by

USGS Map Distribution

Box 25286, Building 810

Denver Federal Center

Denver, CO 80225

\section{Library of Congress Cataloging-in-Publication Data}

\section{Ojakangas, Richard W.}

Sedimentology and provenance of the Early Proterozoic Michigamme Formation and Goodrich Quartzite, northern Michigan: regional stratigraphic implications and suggested correlations / by Richard W. Ojakangas.

p. cm. - (U.S. Geological Survey bulletin; 1904-R)

(Contributions to Precambrian geology of Lake Superior region; ch. R)

Includes bibliographical references.

Supt. of Docs. no.: I 19.3:1904

1. Geology, Stratigraphic-Proterozoic. 2. Geology-Michigan.

3. Michigamme Formation (Mich. and Wis.). 4. Goodrich Quartzite

(Mich.). I. Title. II. Series. III. Series: Contributions to Precambrian geology of Lake Superior region; ch. R.

QE75.B9 no. 1904-R

[QE653.5]

$557.3 \mathrm{~s}-\mathrm{dc} 20$

93-30526

[551.7'15'09774] 


\title{
CONTENTS
}

\author{
Abstract $\quad \mathbf{R 1}$ \\ Introduction R1 \\ General field description, Michigamme Formation $\quad$ R4 \\ Slate members $\quad \mathbf{R 4}$ \\ Bijiki Iron-formation Member $\quad$ R7 \\ Drill hole descriptions $\quad \mathbf{R 7}$ \\ Clark Creek basin drill hole $\quad \mathbf{R 8}$ \\ Dead River basin drill hole $\quad \mathbf{R 8}$ \\ East Baraga basin drill holes $\quad \mathbf{R 8}$ \\ Amasa drill hole $\mathbf{R 1 0}$ \\ Gwinn area drill hole $\quad \mathbf{R 1 0}$ \\ Petrography R10 \\ Chemistry R13 \\ Paleocurrent analysis R16 \\ Metagraywacke and metasiltstone $\quad \mathbf{R} 16$ \\ Goodrich Quartzite R18 \\ Sedimentation R19 \\ Introduction $\mathbf{R} 19$ \\ Goodrich Quartzite R21 \\ Lower slate member, Michigamme Formation $\quad \mathbf{R 2 2}$ \\ Bijiki Iron-formation Member, Michigamme Formation $\quad \mathbf{R 2 2}$ \\ Upper slate member, Michigamme Formation $\quad \mathbf{R 2 2}$ \\ Tectonic model and provenance $\mathbf{R 2 3}$ \\ Stratigraphic implications $\quad \mathbf{R 2 7}$ \\ References cited $\quad \mathbf{R 2 8}$
}

FIGURES

1. Correlation chart for rocks in the Early Proterozoic Animikie basin $\mathbf{R 2}$

2. Generalized geologic-tectonic map of Precambrian rocks, Lake Superior region $\mathbf{R 3}$

3. Generalized geologic map of Precambrian rocks, northern Michigan and northwestern Wisconsin

$\mathbf{R 5}$

4-6. Photographs showing:

4. Graywacke beds in roadcut south of Covington, Michigan R6

5. Graded graywacke beds with refracted cleavage, roadcut east of Covington, Michigan $\mathbf{R 6}$

6. Graywacke beds, measured section southeast of Crystal Falls, Michigan $\mathbf{R 6}$

7. Generalized logs of drill holes DL-4 and DL-5, northern Michigan R9

8. $\mathrm{Q} / \mathrm{F} / \mathrm{L}$ plots of modal analyses of Michigamme Formation graywacke and Goodrich Quartzite R10

9-12. Photomicrographs of:

9. Graywacke, showing abundance of matrix $\quad \mathbf{R 1 3}$

10. Graywacke, showing felsic volcanic rock fragments $\mathbf{R} 13$

11. Graywacke, showing fresh and altered plagioclase R14

12. Goodrich Quartzite, composed mostly of rounded quartz grains 
13-17. Paleocurrent plots of:

13. Michigamme Formation in northern and southern areas $\quad$ R17

14. Copps Formation and Tyler Formation R18

15. Michigamme Formation in northern and southern areas, with all measurements replotted together to interpret direction $\quad \mathbf{R} 19$

16. Goodrich Quartzite outcrops in northern Michigan $\quad \mathbf{R 2 0}$

17. Goodrich Quartzite outcrops with all measurements replotted together to interpret direction $\quad \mathbf{R 2 1}$

18. Photograph of lower slate member of Michigamme Formation in drill core $\mathbf{R 2 2}$

19. $\mathrm{Q} / \mathrm{F} / \mathrm{L}$ plots of average modal analyses of graywacke-slate units of Lake Superior region $\mathbf{R 2 3}$

20. Schematic cross section depicting deposition of Michigamme Formation $\quad$ R24

21. Schematic map of paleogeography at time of sedimentation of Michigamme Formation R26

\section{TABLES}

1. Sedimentological data from measured sections of Michigamme Formation

2. Modal analyses of samples of graywacke from northern exposures of Michigamme Formation and from Goodrich Quartzite R11

3. Modal analyses of graywackes from southern exposures of Michigamme Formation R12

4. Chemical analyses of samples from southern exposures of Michigamme Formation R15

5. Chemical analyses of samples from northern exposures of Michigamme Formation (drill cores) $\quad$ R16 


\title{
Sedimentology and Provenance of the Early Proterozoic Michigamme Formation and Goodrich Quartzite, Northern Michigan-Regional Stratigraphic Implications and Suggested Correlations
}

\author{
By Richard W. Ojakangas 1
}

\begin{abstract}
The Early Proterozoic Michigamme Formation of northern Michigan was deposited in the southeastern part of the Animikie basin. The formation conformably overlies the Goodrich Quartzite and comprises three widespread members-a lower member of thin-bedded shale, siltstone, and sandstone; the Bijiki Iron-formation Member; and an upper member of turbiditic graywacke, siltstone, and mudstone-and a few local members. The Goodrich Quartzite is interpreted as having been deposited in a tidally influenced shallow marine environment. The lower member of the Michigamme is interpreted as having been deposited in a tidally influenced environment, the iron-formation member as having been deposited below wave base in somewhat deeper water, and the upper member as having been deposited in still deeper water with turbidity currents being a major depositional mechanism.

Several lines of evidence including paleocurrents, paleogeographic setting, and neodymium isotopes suggest that the graywacke of the southern part of the outcrop area was derived from the south (Early Proterozoic Wisconsin magmatic terranes, Archean miniplates, and older Early Proterozoic sedimentary units formed on the continental margin), and that the graywacke in the northern area was derived from an Archean terrane to the north. The tectonic model that best fits the available data is a northward-migrating foreland basin.
\end{abstract}

\section{INTRODUCTION}

The Early Proterozoic, dominantly clastic Marquette Range Supergroup (fig. 1), deposited in the eastern part of the Animikie basin in the Upper Peninsula of Michigan and

${ }^{1}$ Department of Geology, University of Minnesota Duluth, Duluth, MN 55812, and U.S. Geological Survey. adjacent Wisconsin, consists of, in ascending order, the Chocolay, Menominee, and Baraga Groups (Cannon and Gair, 1970). A fourth group, the Paint River Group, may be the youngest sequence (Cannon, 1986), but it could instead be remnants of a thrust sheet and therefore not the stratigraphically youngest unit (Cambray, 1987; Sims, 1990; Sims and Schulz, 1992). The entire succession comprises a continental margin assemblage deposited on the south edge of the Archean Superior province. The Menominee Group contains the iron-formations that have long been of economic significance. The Michigamme Formation, the uppermost unit in the Baraga Group of James (1958), is a darkgray to black turbiditic graywacke, siltstone, and mudstone sequence several thousand meters thick. The Tyler and Copps Formations in the vicinity of the Gogebic range in northwesternmost Michigan and adjacent Wisconsin, both also deposited in the Animikie basin, are generally considered correlative with the Michigamme Formation because of proximity and lithologic similarity.

The Michigamme, Tyler, and Copps Formations are present in the southeastern segment of the Animikie basin (fig. 2), on the east side of the 1,100 Ma Midcontinent rift system (Morey, 1983a, b). Most of the outcrop area of the Michigamme Formation is within the Iron River $1^{\circ} \times 2^{\circ}$ quadrangle (Cannon, 1986), and in several $711^{\prime}$ quadrangles of the western part of the Marquette syncline. In some recent publications (Southwick and Morey, 1991; Holst, 1991), the southeastern segment of the Early Proterozoic basin has been called the Baraga basin, but in this report the southeastern segment is considered part of the larger Animikie basin.

Correlations within the larger Animikie basin have been a concern for the last century, largely because of the ironformations in the seven iron ranges of the Lake Superior 


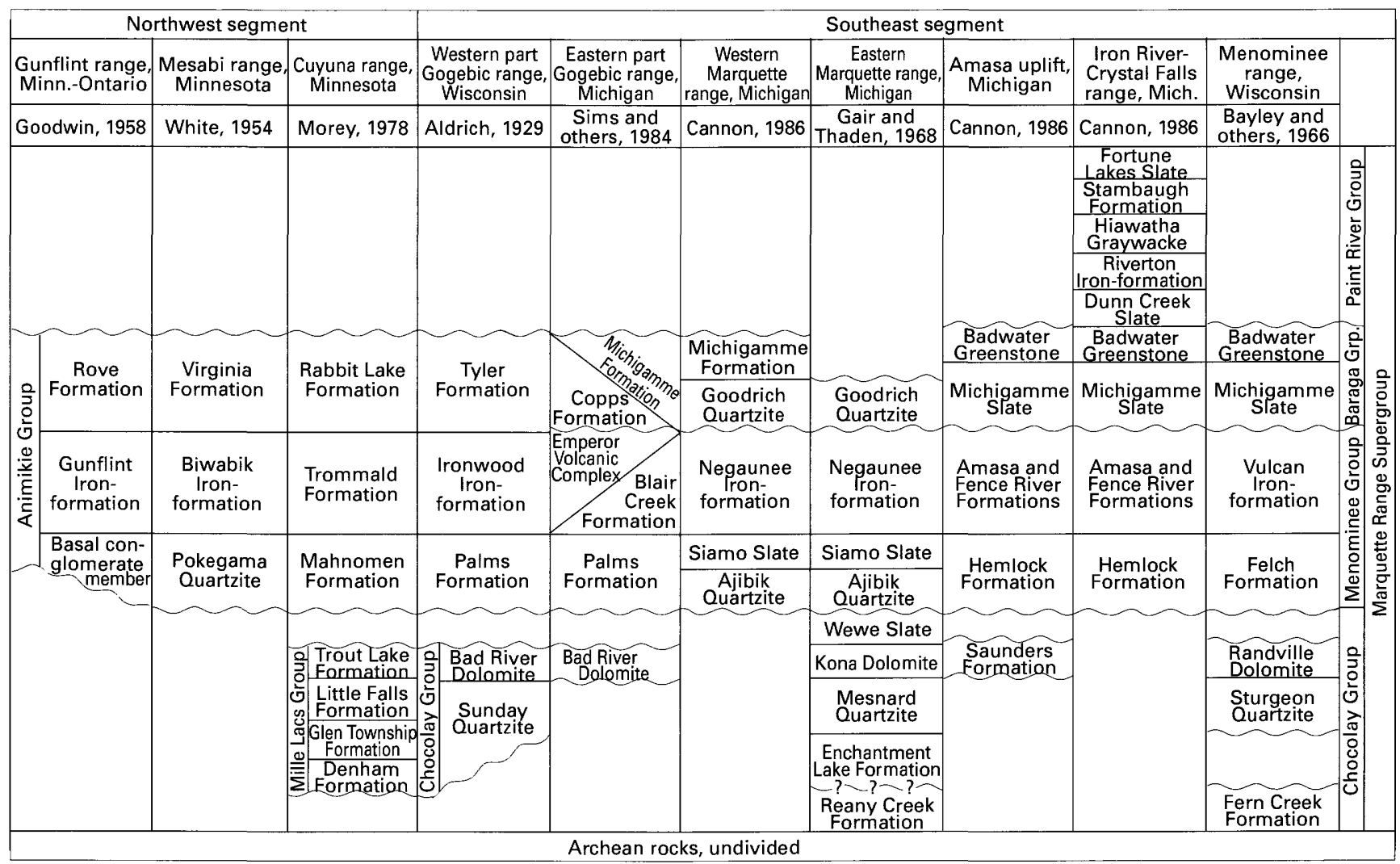

Figure 1. Correlation chart for sedimentary and volcanic rock units of Early Proterozoic age in the Animikie basin. From Morey and Van Schmus (1988). The Animikie basin as used herein follows the usage of Morey and Van Schmus (1988) and differs from the more restricted usage of Southwick and Morey (1991). Southwick and Morey (1991) have shown that the formations within the Mille Lacs Group on the Cuyuna range are mainly fault bounded; a fault separates the Denham Formation from the Glen Township and Little Falls Formations, and the latter two formations are separated from the Trout Lake Formation by another fault. Also recently, workers have correlated the Paint River Group with the Baraga Group on structural grounds (Sims and Schulz, 1992) and have correlated the Badwater Greenstone and the Hemlock Formation (Sims, 1992). Sims (1991) also has placed the Reany Creek Formation in the Late Archean.

region. (See, for example, Van Hise and Bayley, 1897; Leith and others, 1935; James, 1958; Cannon and Gair, 1970; Cannon and Klasner, 1975.) In the most recent synthesis (Morey and Van Schmus, 1988), the Michigamme, Tyler, and Copps Formations of the southeastern segment are correlated with units in the northwestern segment, that is, the Rove, Virginia, and Rabbit Lake Formations of the Gunflint, Mesabi, and Cuyuna ranges, respectively (fig. 1). The Thomson Formation of east-central Minnesota, which has a similar lithology, has also generally been considered correlative of these graywacke units (Morey and Ojakangas, 1970). However, recent structural interpretations complicate the correlations of these units, for northward thrusting has juxtaposed units of differing Early Proterozoic ages in both east-central Minnesota (Southwick and others, 1988; Southwick and Morey, 1991) and the Upper Peninsula of Michigan (Klasner and others, 1991; Gregg, 1993). Southwick and Morey (1991) discussed and illustrated correlation problems between the northwest and southeast segments of the Animikie basin.
Geochronologic data are somewhat equivocal because of the lack of datable crosscutting dikes of Early Proterozoic age. The data, summarized in Morey and Van Schmus (1988), indicate that the Marquette Range Supergroup was deposited during the interval 2,100-1,900 Ma. The age of the Michigamme Formation is probably closer to the younger figure; Sims and Schulz (1992) reported an age of 1,930 Ma on a carbonate-apatite bed in the iron-formation member of the Michigamme Formation in the East Baraga basin. Southwick and Morey (1991) suggested that the correlative Animikie Group in Minnesota may be younger than 1,900 Ma and older than late-tectonic to post-tectonic intrusions 1,820(?)-1,770 Ma.

The rocks of the southeastern segment of the Animikie basin (the study area), which include metavolcanic rocks as well as the thick sequences of metasedimentary rocks, are bordered on the south-across the Niagara fault zone (fig. 2)-by the younger $(\approx 1,850 \mathrm{Ma}) 200-\mathrm{km}$-wide sequence of granitoid and metavolcanic rocks of the Wisconsin magmatic terranes (Morey and Van Schmus, 1988; 

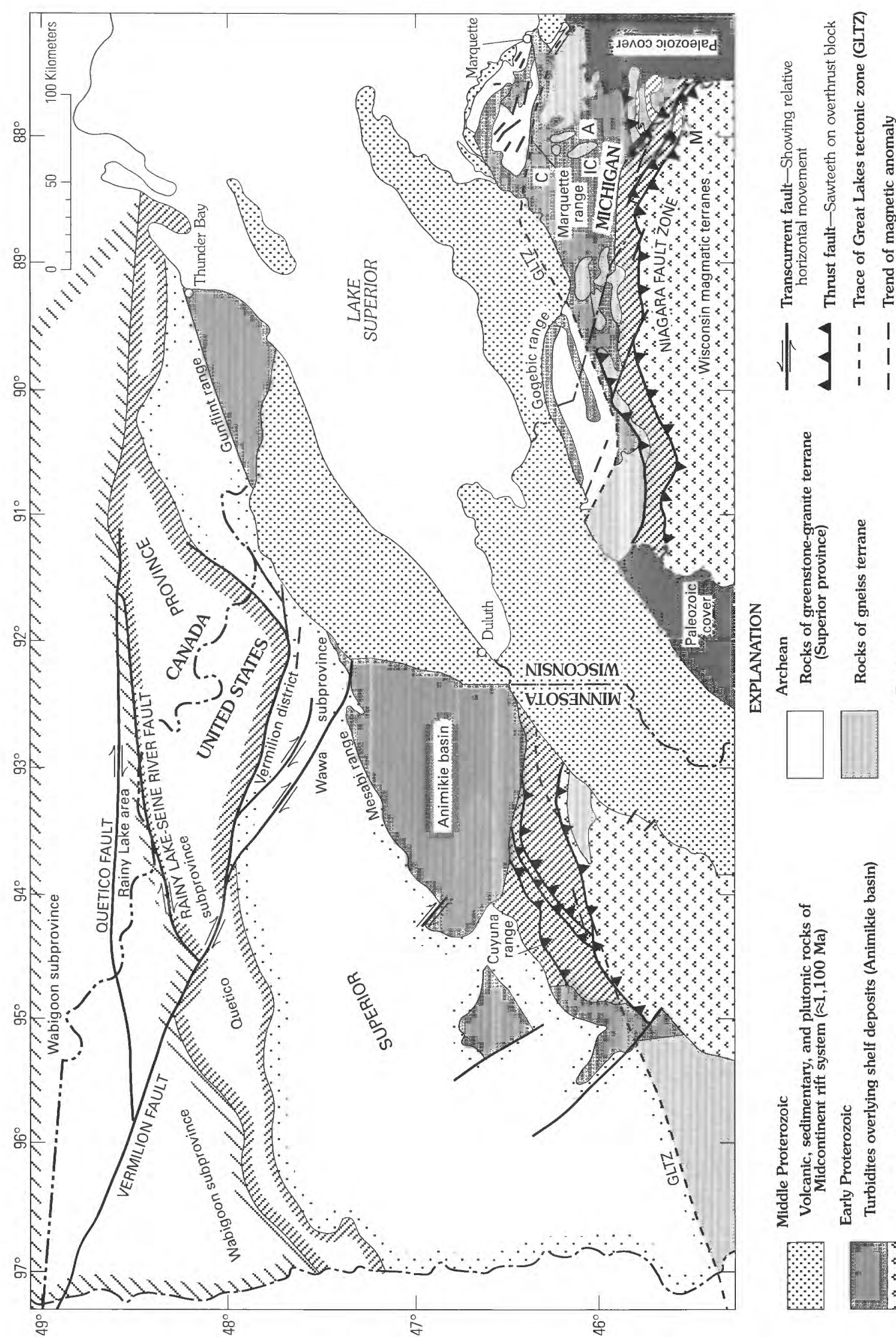

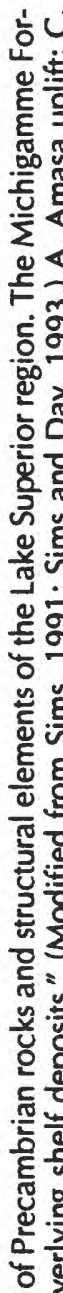

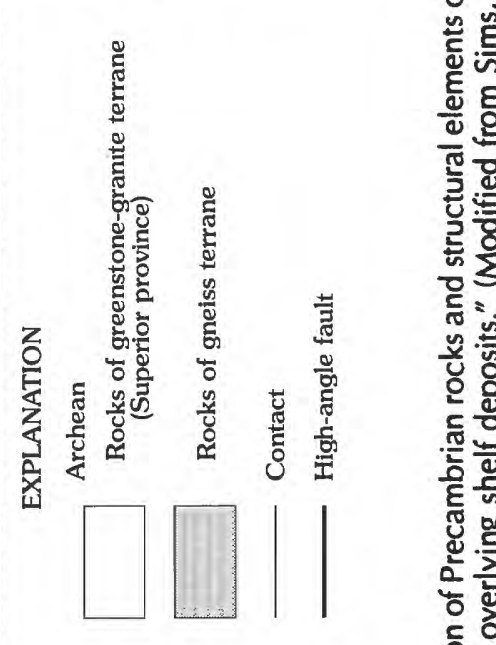

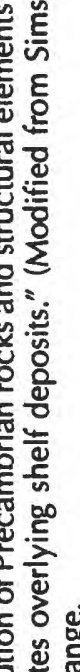

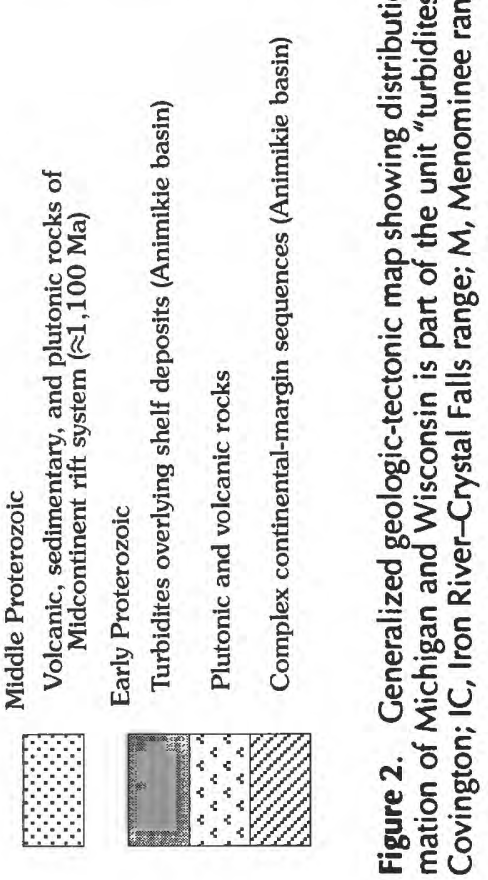


Sims and others, 1989). Whereas the trace element patterns from basaltic volcanic rocks of the Marquette Range Supergroup are characteristic of continental tholeiites (rift volcanics), those of the Wisconsin magmatic terranes (a bimodal suite of basaltic and rhyolitic rocks) are characteristic of tholeiitic and calc-alkalic volcanic rocks of oceanic island arcs (Schulz, 1983; Sims and others, 1989).

The Michigamme Formation was folded, faulted, and metamorphosed during the Penokean orogeny. (See for example, Cannon, 1973; Klasner, 1978; Attoh and Klasner, 1989; Klasner and others, 1991; Holst, 1991; Gregg, 1993.) The Penokean orogen in northern Michigan has been divided into two structural domains (Klasner and others, 1988; Klasner and Cannon, 1989; Klasner and Sims, 1993). The northern domain, north of the Marquette syncline (fig. 3), consists of a foreland-basin thrust belt in which deformation was largely thin skinned (Gregg, 1993); the southern domain, south of the Marquette syncline, consists of a basement arch in which deformation was primarily thick skinned, that is, it involved the Archean basement as well as the Early Proterozoic rocks (Klasner and Sims, 1993). Details on specific areas are presented by Cannon (1974), Puffett (1974), Cannon and Klasner (1980), Foose (1981), Sims and others (1984), Klasner and others (1991), and Gregg (1993), among others.

Klasner and others (1991) interpreted the presence of numerous north-verging folds, thrust faults, and multiple deformation in northern Michigan as the product of collisional tectonics. Holst (1991) compared similar structures in east-central Minnesota to those in Michigan, and Southwick and Morey (1991) also made such comparisons. Because of rather poor outcrops, it is likely that thrusting has disrupted the stratigraphy to a greater extent than has been documented.

The rock units of the southeastern Animikie basin, including the Michigamme Formation, have been metamorphosed to varying degrees; most rocks are in the chlorite zone of the greenschist facies, but higher grade rocks crop out in the southern and eastern parts of the study area (James, 1955; James and others, 1961; Cannon, 1973; Klasner, 1978; Morey, 1978). A Rb/Sr isochron age of $1,820 \pm 50 \mathrm{Ma}$ (Sims and others, 1984) gives a minimum age for the metamorphism. The metamorphism and deformation occurred during the Penokean orogeny, about 1,850 Ma. (See for example, Sims and Peterman, 1983; Holst, 1991; Klasner and others, 1991.)

The Late Archean Great Lakes tectonic zone (fig. 2; Sims and others, 1981; Sims, 1991), which separates an Archean greenstone-granite terrane to the north from a southern gneiss terrane as old as 3,600 Ma (Sims and Peterman, 1983), divides the Early Proterozoic basin into a northern stable cratonic zone and a southern more mobile zone. North of the tectonic front, the Early Proterozoic sedimentary rocks generally have been subjected to only low-grade metamorphism and moderately weak folding, whereas south of it the rocks are intensely deformed by multiple deformations and locally are metamorphosed to amphibolite facies.

\section{GENERAL FIELD DESCRIPTION, MICHIGAMME FORMATION}

The Michigamme Formation has been divided into three major members. In ascending order, these are the lower slate member, the Bijiki Iron-formation Member, and the upper slate member (Leith and others, 1935; Tyler and Twenhofel, 1952; Cannon and Klasner, 1977). In specific areas, local members such as the Greenwood Iron-formation Member and the Clarksburg Volcanics Member have been designated (Cannon, 1974; 1975). A generalized columnar section for the Michigamme Formation in the Dead River basin, north of the Marquette trough, was presented by Puffett (1974).

\section{Slate Members}

Determining the stratigraphic position of graywacke-siltstone-slate (metamorphosed graywacke, siltstone, and mudstone) in the scattered outcrops in the large area between the Marquette syncline and the Gogebic range is generally not possible, because of (1) generally broad open folds that may repeat the section over broad areas; (2) the presence of thrust faults (Klasner and others, 1991; Gregg, 1993); and (3) multiple deformation. Consequently, the drill holes described following are invaluable for establishing the lithology of the lower and upper members of the formation. Briefly, examination of the cores indicates that the lower member is finer grained than the upper member and that the upper member, although dominantly fine grained, contains several graded graywacke beds.

Various sedimentary features are present in the graywacke beds, including graded beds with internal Bouma intervals, mud chip (rip-up) layers, load features, concretions, and flat soles with a lack of primary scour and tool marks. Cleavage is prominent in all exposures, and refracted cleavage is the rule in the graywacke-slate sequences.

The best exposures of well-developed beds of graywacke and slate are roadcuts along U.S. Highway 141 from Covington (fig. 3) southward for $20 \mathrm{~km}$ (fig. 4) and a few kilometers along Michigan Highway 28 both east and west of the junction at Covington with U.S. Highway 141. Other accessible outcrops showing excellent beds are present at Little Mountain just south of L'Anse; near the west end of Lake Michigamme (here the formation contains staurolite crystals as much as $1 \mathrm{~cm}$ long); at Little Bull Rapids on the Paint River south of Crystal Falls; and at Hemlock Rapids, also on the Paint River, northeast of the town of Iron River. 


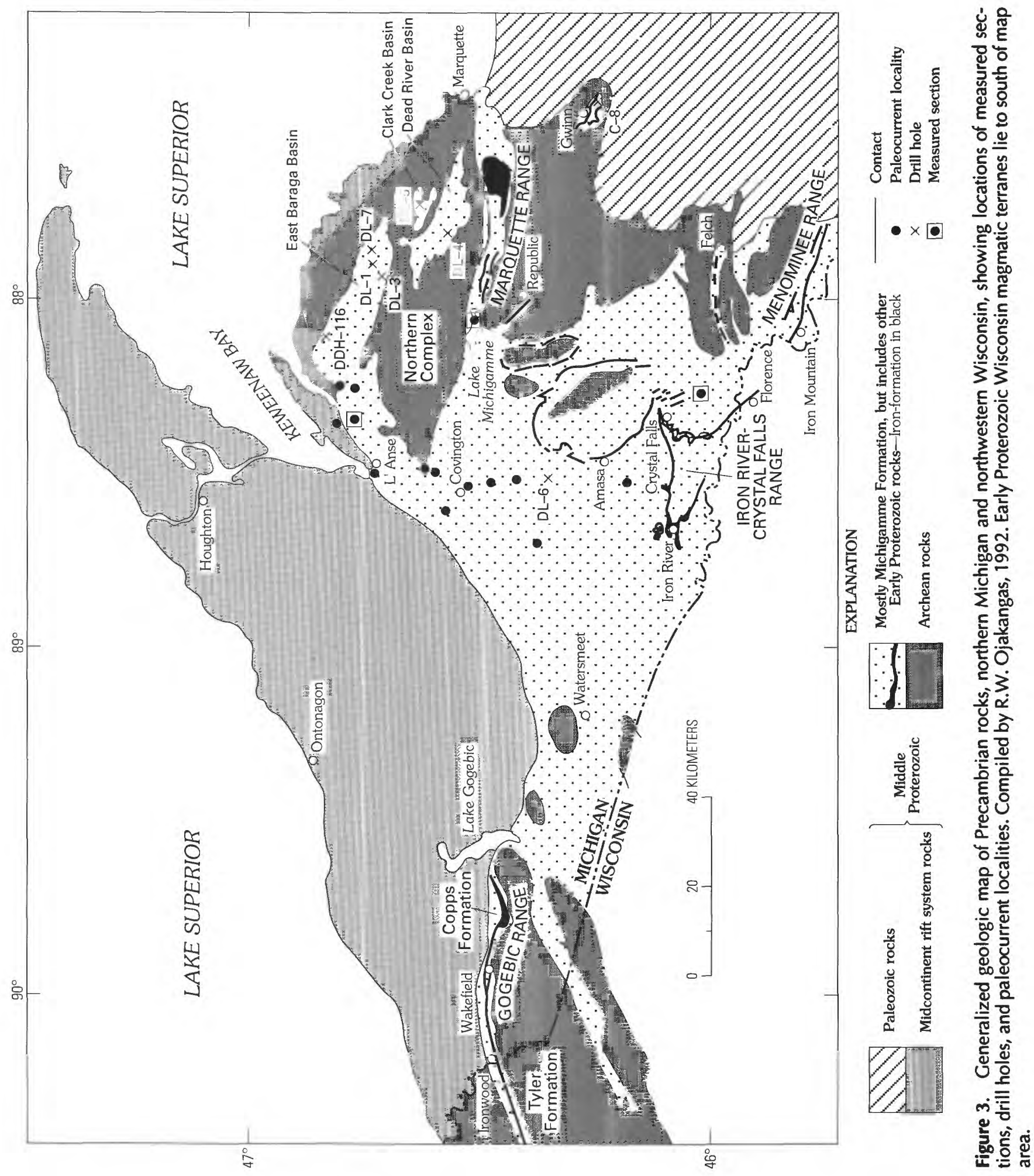




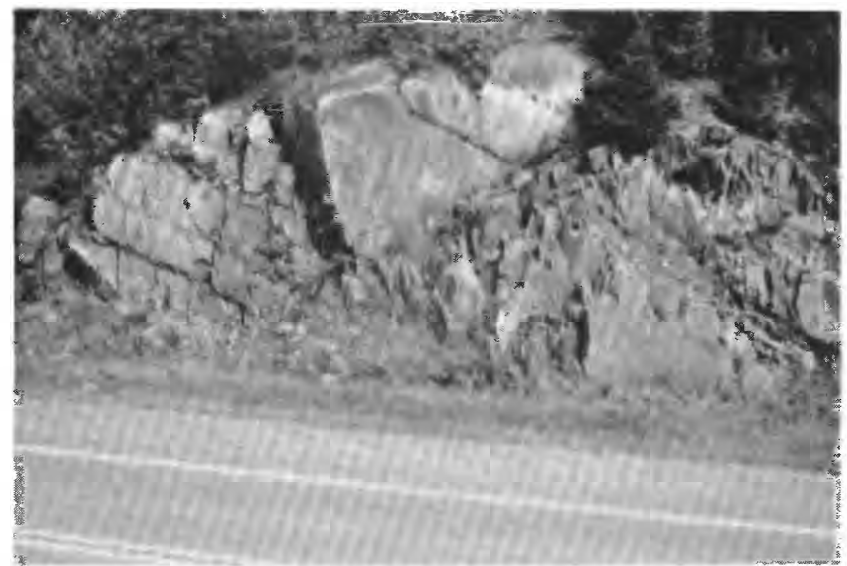

Figure 4. Roadcut showing 1- to 2-m-thick graywacke beds of Michigamme Formation. Stratigraphic tops are to right (south). The void spaces at upper right are result of the weathering out of concretions. Roadcut on U.S. Highway 141 about $4.3 \mathrm{~km}$ south of the town of Covington ( $5 \mathrm{~km}$ south of the intersection of Michigan Highway 28 and U.S. Highway 141). Outcrops total about $4 \mathrm{~m}$ high.

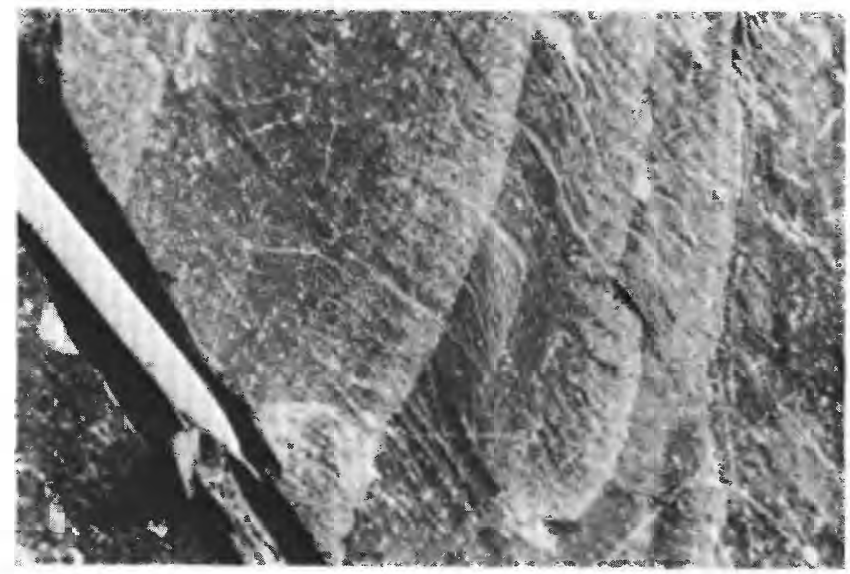

Figure 5. Graded graywacke beds of Michigamme Formation with refracted cleavage. Tops are to left (north). Roadcut on Michigan Highway 28 about $1.6 \mathrm{~km}$ east of the town of Covington ( $5 \mathrm{~km}$ west of the intersection of U.S. Highway 41 and Michigan Highway 28). Pencil for scale (about $0.8 \mathrm{~cm}$ wide).

The Michigamme Formation is fine grained and predominantly slaty over much of the study area, and especially north of an east-west line positioned a few kilometers north of Covington (figs. 2,3) and including the East Baraga basin (fig. 3). This facies relation is shown on the geologic map of the Iron River $1^{\circ} \times 2^{\circ}$ quadrangle (lat $46^{\circ}-47^{\circ} \mathrm{N}$., long $88^{\circ}-90^{\circ}$ W.; Cannon, 1986). Cannon mapped unit Xbms (slate) in the northern part of the quadrangle, and unit Xbmg (metamorphosed graywacke) occupies the southern twothirds of the quadrangle. Cannon implied by the mapped stratigraphic sequence in the Lake Michigamme area on the east edge of the quadrangle that unit Xbms is the lower

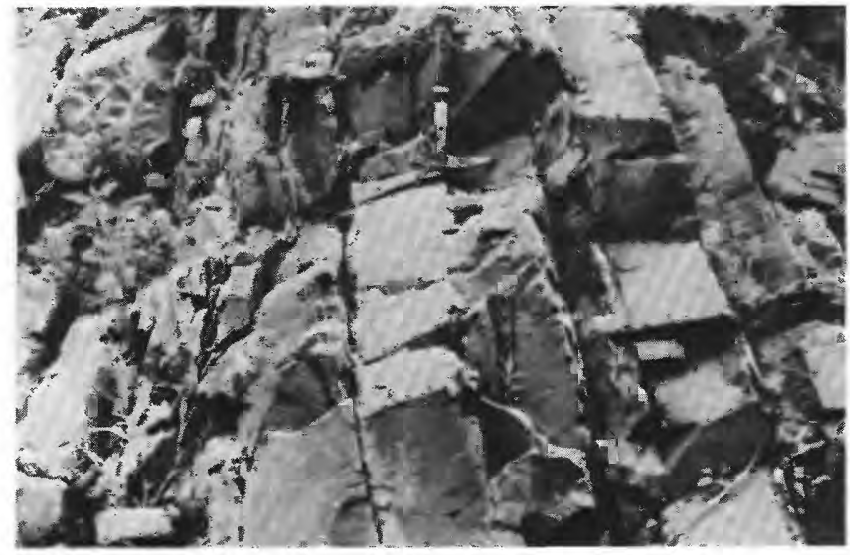

Figure 6. Graywacke beds of Michigamme Formation in measured section at Little Bull Rapids on the Paint River, about $10 \mathrm{~km}$ southeast of town of Crystal Falls. Tops are to left, so beds are slightly overturned. Hammer is $27 \mathrm{~cm}$ long.

member of the Michigamme and that unit Xbmg is the upper member; the two units are separated by an iron-formation unit. However, drill-hole data cited herein following suggest that unit Xbms of Cannon is instead largely the upper member, rather than the lower member. It is noteworthy that Cannon's metamorphosed graywacke unit (Xbmg) is dominantly fine grained to medium-grained graywacke with abundant intercalated slate; even those graywacke beds that are several meters thick are fine grained.

In the roadcuts along a 20-km-long stretch of U.S. Highway 141 south of Covington, graywacke is dominant over slate, as is indicated on the Iron River $1^{\circ} \times 2^{\circ}$ quadrangle (Cannon, 1986). Beds as much as $3 \mathrm{~m}$ thick are common, and a few are as much as $6 \mathrm{~m}$ thick; nevertheless, all beds are fine grained or medium grained. Grading is common (fig. 5) and Bouma A (A-E), B, and A-B beds are the norm; the soles of the beds are generally very flat and have sharp contacts with the underlying slate. A few sole marks are present, as is small-scale crossbedding. Pseudo-sole marks, pseudo-ripple marks, and pseudo-flame structures are the products of bedding-cleavage intersections. Ubiquitous concretions are generally rotated into cleavage, as are rare mudchips. Also present are clastic dikes (subparallel to cleavage), convolutions, soft-sediment deformation features, and load features.

Two well-exposed sections of graywacke-slate were measured and studied in detail (table 1). One is a 75-m-thick section at the dam on the Paint River at Little Bull Rapids, about $10 \mathrm{~km}$ southeast of Crystal Falls ( $\mathrm{N}^{1} / 2 \mathrm{SW}^{1} / 4 \mathrm{sec}$. 24 , T. 42 N., R. 32 W.), as shown in figure 6 , and the other is a 13-m-thick section at the west end of Ramsey Island in the central part of Lake Michigamme (fig. 3). A third measured section, $60 \mathrm{~m}$ thick, was studied in less detail in the gorge on Silver River (NW corner sec. 26, T. 51 N., R. 32 W.), 11 $\mathrm{km}$ northeast of L'Anse. At the latter locality, pseudo-sole 
Table 1. Sedimentological data from measured sections of Michigamme Formation

[Grain size: M, medium; F, fine. Leader (-), statistically none, locality II; not determined, locality III. Proximality index is the percentage of graywacke beds starting with Bouma A plus one-half of the percentage of beds starting with Bouma B (Walker, 1967)]

\begin{tabular}{|c|c|c|c|}
\hline & & Locality & \\
\hline & $\begin{array}{c}\text { I } \\
\text { Little Bull } \\
\text { Rapids }\end{array}$ & $\begin{array}{c}\text { II } \\
\text { Lake } \\
\text { Michigamme }\end{array}$ & $\begin{array}{l}\text { III } \\
\text { Silver River } \\
\text { Falls }\end{array}$ \\
\hline Section total thickness (meters) & 74.25 & 12.7 & 60 \\
\hline $\begin{array}{l}\text { Number and percent graywacke beds } \\
\text { Percent thin siltstone and sandstone } \\
\text { Percent argillite }\end{array}$ & $\begin{array}{c}63 \text { (30.7 pct.) } \\
(68.9) \\
(0.4)\end{array}$ & $\begin{array}{l}14 \text { (99.5 pct.) } \\
-\quad(0.5)\end{array}$ & $\begin{array}{l}(18 \text { pct. }) \\
)^{-(82)}\end{array}$ \\
\hline $\begin{array}{l}\text { Graywackes: Percent graded } \\
\text { Average grain size } \\
\text { Average thickness (centimeters) } \\
\text { Range, thickness (centimeters) }\end{array}$ & $\begin{array}{l}70 \\
\text { M-F } \\
36 \\
8-385\end{array}$ & $\begin{array}{l}100 \\
F \\
90 \\
30-240\end{array}$ & $\begin{array}{l}\text { few } \\
\text { F } \\
<10 ? \\
2-120\end{array}$ \\
\hline $\begin{array}{l}\text { Number and percent, } \\
\text { Bouma A beds } \\
\text { AB beds } \\
\text { ABC beds } \\
\text { B beds } \\
\text { Number ungraded, massive } \\
\text { Number ungraded, laminated } \\
\text { Proximality index }\end{array}$ & $\begin{array}{l}21(33 \text { pct.) } \\
16(25) \\
1(1) \\
6(10) \\
8(13) \\
11(17) \\
86\end{array}$ & $\begin{array}{l}12 \text { (86 pct.) } \\
- \\
2(14) \\
- \\
- \\
- \\
100\end{array}$ & $\begin{array}{l}- \\
\text { - } \\
\text { few } \\
\text { many } \\
- \\
-\end{array}$ \\
\hline
\end{tabular}

marks, formed by the intersection of bedding and cleavage, are present on graywacke beds; the soles are generally very flat, grading is not well defined, and load casts, zones of soft-sediment deformation, and convolutions exist.

\section{Bijiki Iron-formation Member}

The Bijiki Iron-formation Member of Van Hise and Bayley (1897) is a relatively thin (as much as $60 \mathrm{~m}$ ), lithologically variable unit. It is fine grained, thin bedded, and cherty (white and black); it contains black slate (cleaved), varicolored argillite-siltstone (lacking cleavage), iron carbonate, and, locally, iron oxides or grunerite. More than 5 million tons (2,000-pound tons) of high-grade iron oxide ore has been produced from the formation (Klasner and Cannon, 1978). The unit is best developed in the vicinity of Lake Michigamme, at the west end of the Marquette syncline, and can be traced westward around the west end of the northern complex of the Marquette district in drill cores as well as by geophysical means. The extent of the member is best displayed on a map by the Cleveland-Cliffs Iron Company (1975). The occurrence of iron-formation at several horizons in the Michigamme Formation creates a stratigraphic problem. Structural repetitions may be responsible for at least some of these occurrences; correlation, therefore, is difficult. For further detail, see the description of map units in the Iron River $1^{\circ} \times 2^{\circ}$ quadrangle (Cannon, 1986).

In the Negaunee quadrangle (Puffett, 1974), iron-formation is present at the approximate stratigraphic position of the Bijiki; exposures in sec. 15, T. 48 N., R. 26 W. (Puffett, 1974, p. 37) consist of thinly bedded chert, goethite-limonite, and argillite. The Greenwood Iron-formation Member in the Greenwood quadrangle (Cannon, 1974) also is approximately stratigraphically equivalent to the Bijiki. The Bijiki can be traced as a magnetic high across the northern part of the Witch Lake 15' quadrangle (Cannon and Klasner, 1976a).

Phosphorite has been described from iron-formation at two localities in the Baraga basin (Mancuso and others, 1975), as well as elsewhere in the lowermost $100-200 \mathrm{~m}$ of the Michigamme Formation (Cannon and Klasner, 1976b).

\section{DRILL HOLE DESCRIPTIONS}

A few drill holes penetrate much or all of the Michigamme Formation in the study area. Six vertical holes (fig. 3) were drilled in 1977-1978 by Bendix Field Engineering 
Corporation, which was subcontracted by the Michigan Geological Survey and funded by the U.S. Department of Energy. J \& L Steel Company drilled one vertical hole, and Cleveland-Cliffs Mining Company and Minatome Corporation drilled an inclined hole in 1983. These eight holes were drilled as stratigraphic test holes ${ }^{2}$ for assessment of uranium potential (Trow, 1979). In general, the same three members of the formation that crop out in the area are present in the drill holes-(1) the lower slate member, (2) the Bijiki Ironformation Member, and (3) the upper slate member. The cores consist largely of black slate, metasiltstone, and minor metagraywacke; carbon and sulfide minerals are common. Trow (1979) has described the cores and presented some chemical data. The iron-formation in most of the drill cores consists of thin beds of white chert, brown-tinged iron carbonates, and minor iron oxides. Iron sulfides are locally present. The Bijiki in the drill cores was described in detail by Trow $(1979$, p. 24-26).

\section{Clark Creek Basin Drill Hole}

Bendix's drill hole DL-5 in the Clark Creek basin (fig. 3 ) was logged and sampled (fig. 7). The hole penetrated 233 $\mathrm{ft}$ of the upper slate member, $47 \mathrm{ft}$ of the Bijiki Iron-formation Member, $146 \mathrm{ft}$ of the lower slate member, and $94 \mathrm{ft}$ of the Goodrich Quartzite before ending in Archean metarhyolite.

Argillite and siltstone are dominant in the upper member, but some graded graywacke beds (Bouma A, A-B, B, and A-B-C) as much as $10 \mathrm{~cm}$ thick are present. The Bijiki consists of chert and carbonate with interbedded black slate; a possible stromatolite layer $30 \mathrm{~cm}$ thick was logged in the original study (Trow, 1979), but this may be a tectonically deformed carbonate layer.

Graywacke is essentially absent in the lower member. Rather, thin (less than $2 \mathrm{~cm}$ thick) siltstone beds alternate with thin argillite beds, and black shale partings alternate with thin light-tan sandstone beds that are similar to those in the underlying Goodrich Quartzite.

\section{Dead River Basin Drill Hole}

Bendix's drill hole DL-4 (4A and 4B) in the Dead River basin (fig. 7) intersected $2,890 \mathrm{ft}(2,630 \mathrm{ft}$ actual thickness according to Trow, 1979) of the upper member, $40 \mathrm{ft}$ of the Bijiki, and $93 \mathrm{ft}$ of Goodrich Quartzite; it penetrated weathered Archean tonalite basement at 3,119 ft. I reinterpreted the upper $33 \mathrm{ft}$ of the Goodrich as assigned by Trow as being

\footnotetext{
${ }^{2}$ These drill holes were logged in feet and are reported herein in feet. To convert to meters, multiply feet $\times 0.3048$.
}

the lower member of the Michigamme Formation, for it closely resembles that member in hole DL -5 . Thus, the thickness of the Goodrich is about $60 \mathrm{ft}$.

The upper member in hole DL-4 is markedly coarser grained than in the other holes, as was noted by Trow (1979, p. 34). Slate is the dominant lithology, but medium- to coarse-grained graded graywacke beds are abundant. Bouma A, A-B, A-B-C, and A-B-C-D beds are present; many beds are as thick as 1 meter, and a few are 2-3 m thick. However, many beds lack grading. Because of the great thickness of the upper member $(2,630 \mathrm{ft})$ and its general uniformity, I did not $\log$ the entire member; only the lower $400 \mathrm{ft}$ was inspected box-by-box, and only every sixth core box (each with $15 \mathrm{ft}$ of core) was inspected for the bulk of the member.

The Bijiki Iron-formation Member is a unit of variable lithology, consisting of white cherty-carbonate rock, pyritic black slate with massive sulfide beds as much as $8 \mathrm{~cm}$ thick, and minor graphite-rich beds.

The underlying lower slate member as reinterpreted consists of laminated argillite and thin sandstone.

The lowest unit in the drill hole, the Goodrich Quartzite, consists of an upper zone of thin-bedded sandstone interlayered with very thin black shale, and a lower zone of thicker massive gray sandstone with sparse black shale partings. The contact with the underlying Archean tonalite is sharp and unconformable, and the tonalite is only slightly weathered.

\section{East Baraga Basin Drill Holes}

Three holes-DL-1, DL-3, and DL-7-were drilled by Bendix in the East Baraga basin, as designated in figure 3. Hole DL-1 penetrated nearly $2,100 \mathrm{ft}(1,978 \mathrm{ft}$ actual thickness according to Trow, 1979) of the upper slate member, which contains only a few graywacke beds; it did not reach Archean basement. Hole DL-3 was terminated at 1,634 ft after penetrating $1,471 \mathrm{ft}$ of the upper member. Hole DL-7 penetrated $326 \mathrm{ft}$ ( $285 \mathrm{ft}$ actual thickness according to Trow, 1979) of the upper slate member, $86 \mathrm{ft}$ of Bijiki Iron-formation Member, and, below, weathered Archean granite. Apparently neither the lower member of the Michigamme Formation nor the Goodrich Quartzite was deposited here; this area must have been a topographic high during Goodrich and early Michigamme time, as noted by Trow (1979).

About $21 \mathrm{~km}$ northwest of hole DL-7, J \& L Steel Company drilled hole DDH-116 as a uranium test. This drill hole penetrated $847 \mathrm{ft}$ of the upper member, which consists of carbonaceous, chloritic, and pyritic argillite with only minor graywacke; $70 \mathrm{ft}$ of Bijiki Iron-formation Member; and bottomed in Archean granite (Burns, 1975). As in drill hole DL-7, the lower slate member is missing, presumably because of nondeposition. 
DEAD RIVER BASIN

DL-4

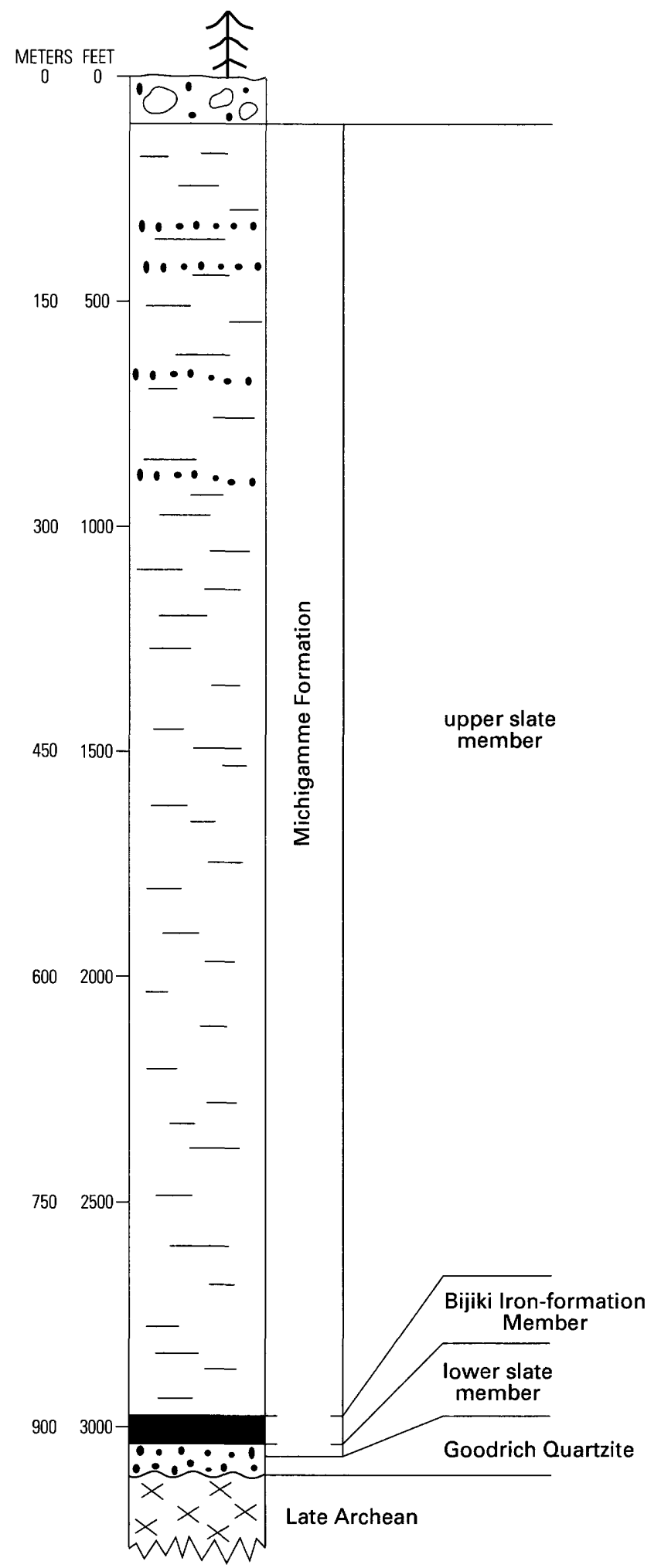

CLARK CREEK BASIN

DL-5

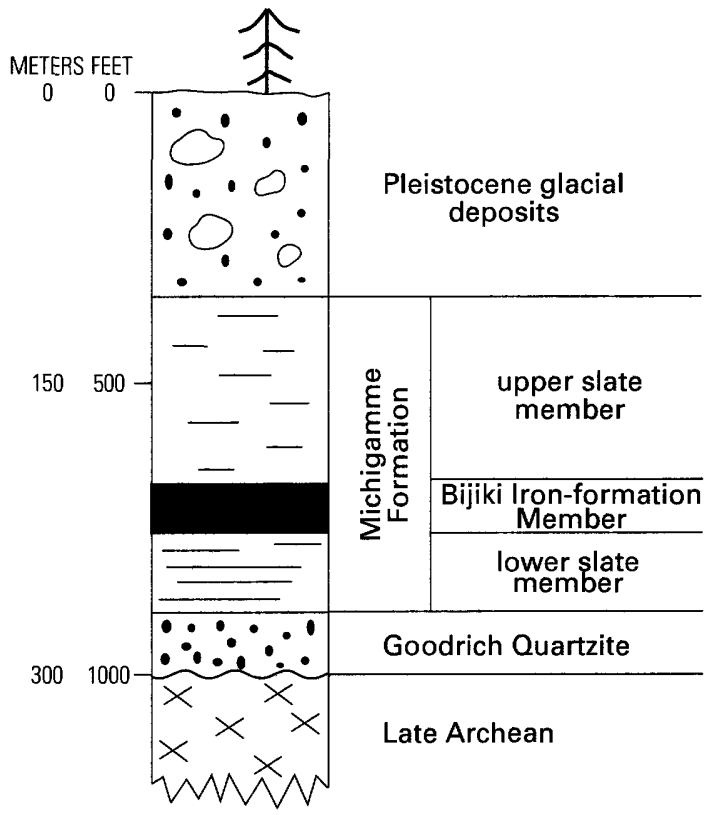

Figure 7. Generalized logs of drill holes $\mathrm{DL}-4$ and $\mathrm{DL}-5$, northern Michigan. Locations shown in figure 3. Total depth not given. 


\section{Amasa Drill Hole}

Bendix's hole DL-6 was drilled about $14 \mathrm{~km}$ northnorthwest of the town of Amasa (fig. 3). It was terminated at $1,093 \mathrm{ft}$ after penetrating a true stratigraphic thickness of $286 \mathrm{ft}$ of alternating carbon-rich and carbonate-rich chloritic graywacke and argillite intercalated with cherty and slaty layers of iron-formation (Trow, 1979). Trow interpreted the cherty and slaty layers of iron-formation to be either the Bijiki Iron-formation Member or the lower slate member.

\section{Gwinn Area Drill Hole}

Drill hole C-8, an inclined 900-ft hole near the town of Gwinn (fig. 3), about $32 \mathrm{~km}$ south of Marquette, was drilled jointly by Cleveland-Cliffs Mining Company and Minatome Corporation in 1983 in search of uranium. The upper $102 \mathrm{ft}$ of conglomerate, in which chert and hematite clasts, gritstone, and sandstone are arranged into 15 fining-upward (fluvial?) sequences, is likely post-Proterozoic in age, for Paleozoic rocks blanket the area just $3 \mathrm{~km}$ to the south of the drill hole. A thickness of about $100 \mathrm{ft}$ of black slate and minor graywacke beds overlies about $140 \mathrm{ft}$ of iron-formation. These rocks overlie about $400 \mathrm{ft}$ of black graphitic slate with minor pyritic laminae and thin beds of graywacke; 36 $\mathrm{ft}$ of basal arkose lies on Archean granite. The penetrated granite contains a number of "fresh" granite zones and altered shear zones, features which may indicate the presence of a major shear zone at the base of the Proterozoic section.

\section{PETROGRAPHY}

Most of the graywacke from the Michigamme Formation is too fine grained, recrystallized, cataclasized, or altered to allow determination of the original ratios of constituents; therefore, most petrographic observations are qualitative. Some petrographic information gleaned from drill cores has been provided by Trow (1979). One of Trow's observations was that the upper member lacks potassium feldspar; however, I noted orthoclase and microcline in many thin sections, and I verified their presence by staining thin section heels. Much potassium feldspar has undoubtedly been altered to sericite.

A total of 28 thin sections of better preserved Michigamme graywacke were point-counted (600 points each) (tables 2, 3). Fourteen samples are from the "northern area" (north of the arbitrary east-west line through Covington), including three drill core samples, and 14 are from the "southern area." Of the 28 samples, 19 plot on a $Q / F / L$ diagram as arkosic graywackes, 7 as feldspathic graywackes, and 2 as sublithic graywackes (fig. 8); however, these rock names probably do not reflect the original compositions of the graywackes, as discussed following.

$\mathrm{Q} / \mathrm{F} / \mathrm{L}$ ratios (quartz/feldspar/lithics or rock fragments) were calculated for each of the 28 samples. Prior to making

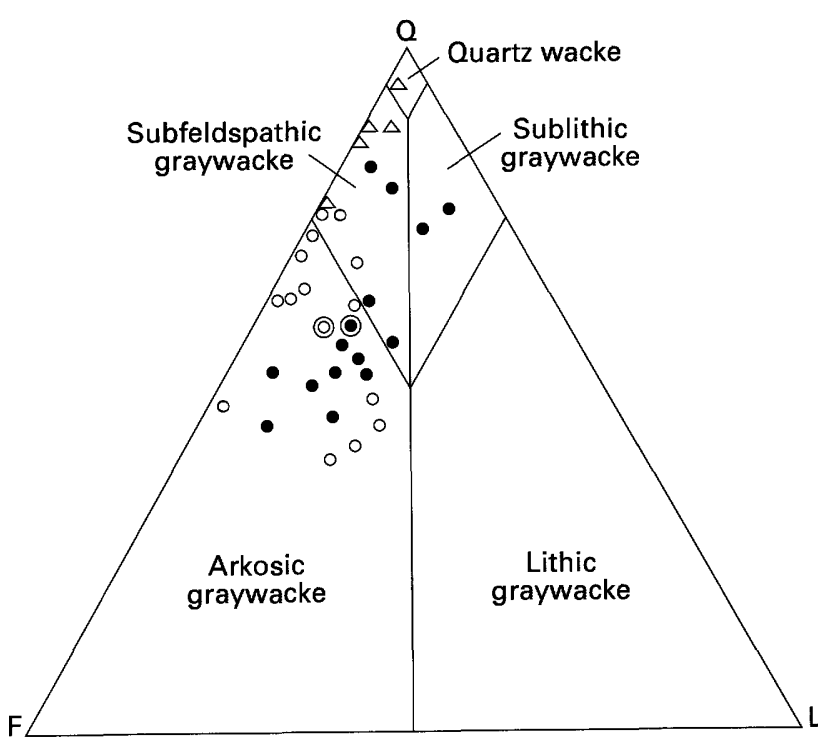

EXPLANATION

- Northern Michigamme graywacke
Mean of northern Michigamme
graywacke samples
- Southern Michigamme graywacke
(-) Mean of southern Michigamme
graywacke samples
$\triangle$ Goodrich Quartzite

Figure 8. $Q / F / L$ plots of modal analyses of 28 thin sections of graywacke of Michigamme Formation and 5 thin sections of Goodrich Quartzite. Q-pole, common (monocrystalline) quartz; F-pole, all feldspars; L-pole includes volcanic and metamorphic rock fragments. The rock fragments include polycrystalline quartz grains and metachert. Triangle modified from Pettijohn and others (1987).

the $\mathrm{Q} / \mathrm{F} / \mathrm{L}$ determinations, I made two adjustments of the original point-count data (tables 2, 3): (1) The plutonic rock fragment percentages were divided equally between feldspar and quartz, because the " $\mathrm{L}$ " component in standard sedimentological procedures generally excludes plutonic fragments. (2) Polycrystalline quartz (recrystallized and sutured types) and chert were counted as metamorphic rock fragments in 15 of the 28 samples. The other 13 samples contain large quantities of recrystallized quartz interpreted to indicate deformation after deposition rather than derivation from metamorphic source rocks; therefore, this quartz was not plotted as rock fragments on the " $L$ " pole. The 14 northern samples have an average $\mathrm{Q} / \mathrm{F} / \mathrm{L}$ ratio of $61: 27: 12$, and the 14 southern samples have an average $Q / F / L$ ratio of 60:31:9. Thus, there is no appreciable difference between the average compositions of samples from the two areas, although differences might have existed prior to postdepositional changes. Note that the ranges of the three constituents are large (tables 2,3 ).

The fine-grained matrix of chlorite, sericite, biotite, epidote, and fine-grained quartz-feldspar in the Michigamme Formation samples totals from 20 to 77 percent $(\overline{\mathrm{X}}=53$ percent) in the 28 samples (fig. 9). This matrix may be in 


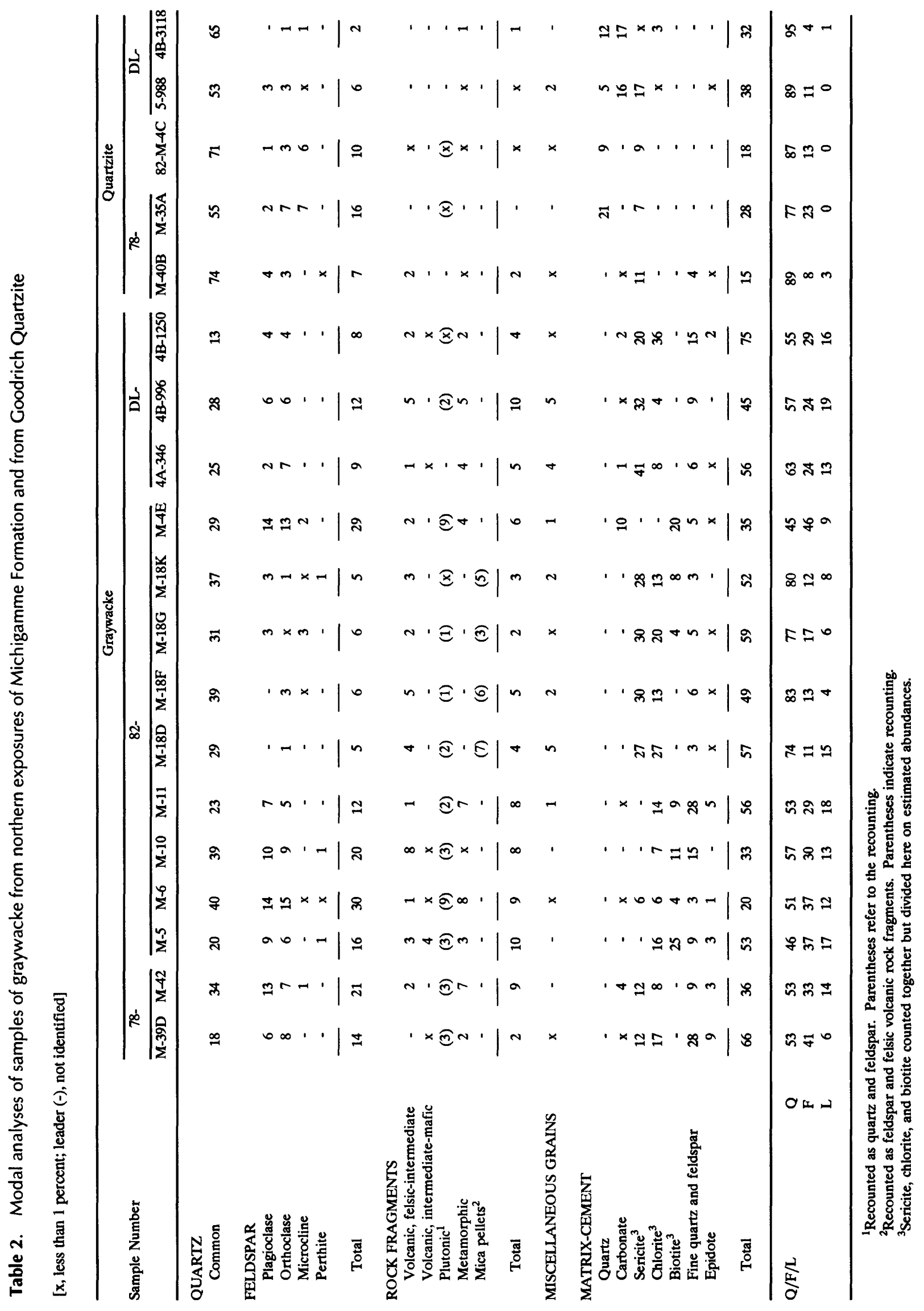




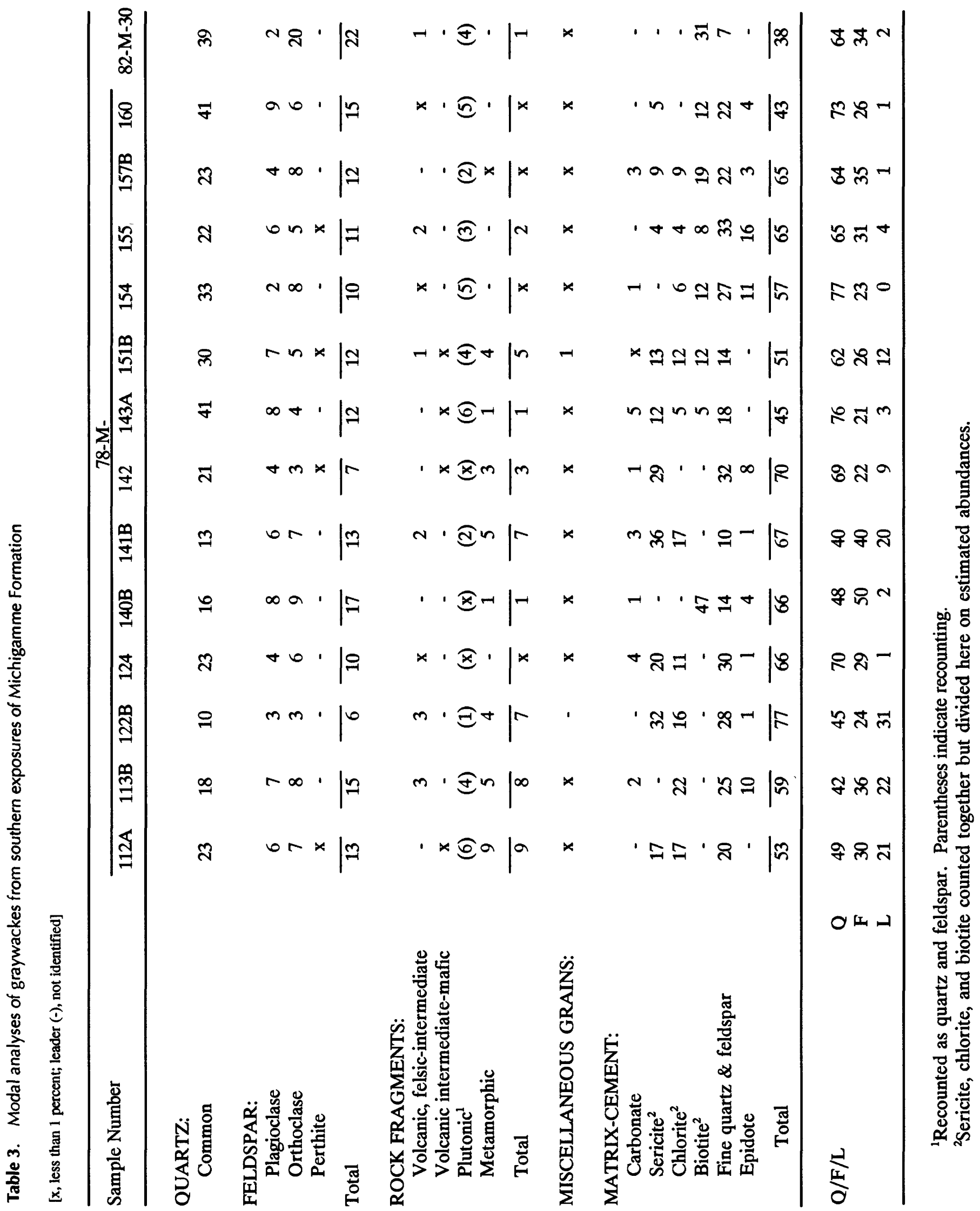




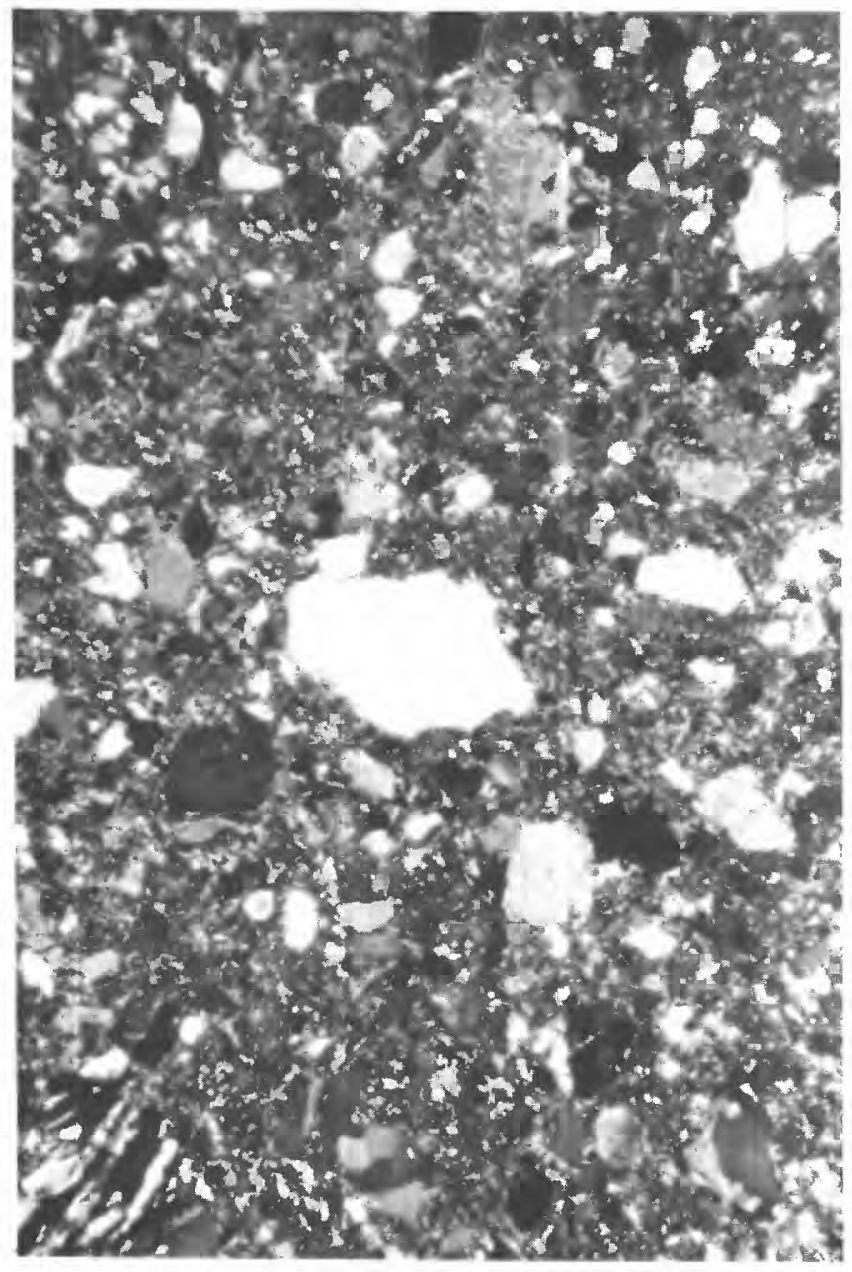

Figure 9. Photomicrograph of graywacke of Michigamme Formation showing abundance of matrix. Most distinguishable sand grains in this view are quartz. Field of view about $1.8 \mathrm{~mm}$ wide. Sample 78-M-141B from roadcut on U.S. Highway 141 about $8 \mathrm{~km}$ south of town of Covington.

part or totally a product of alteration and recrystallization of felsic volcanic rock fragments, other soft rock fragments such as intraformational shale chips, and possibly even feldspar. A total of 24 of the 28 samples contain felsic-intermediate volcanic rock fragments, varying in amount from a trace to 16.8 percent $(\bar{X}=4.4$ percent) in the 14 northern samples (fig. 10) and from zero to 12.9 percent ( $\bar{X}=2.8$ percent) in the 14 southern samples. In four of the northernmost graywacke samples from L'Anse, 3-7 percent of the grains are "mica pellets," which are interpreted as totally altered felsic volcanic rock fragments or possibly feldspar grains.

Plagioclase and potassium feldspar (orthoclase, microcline, and minor perthite) are present in subequal amounts; most is altered, but some is fresh (fig. 11). Plutonic ("granitic") rock fragments of plagioclase-quartz or

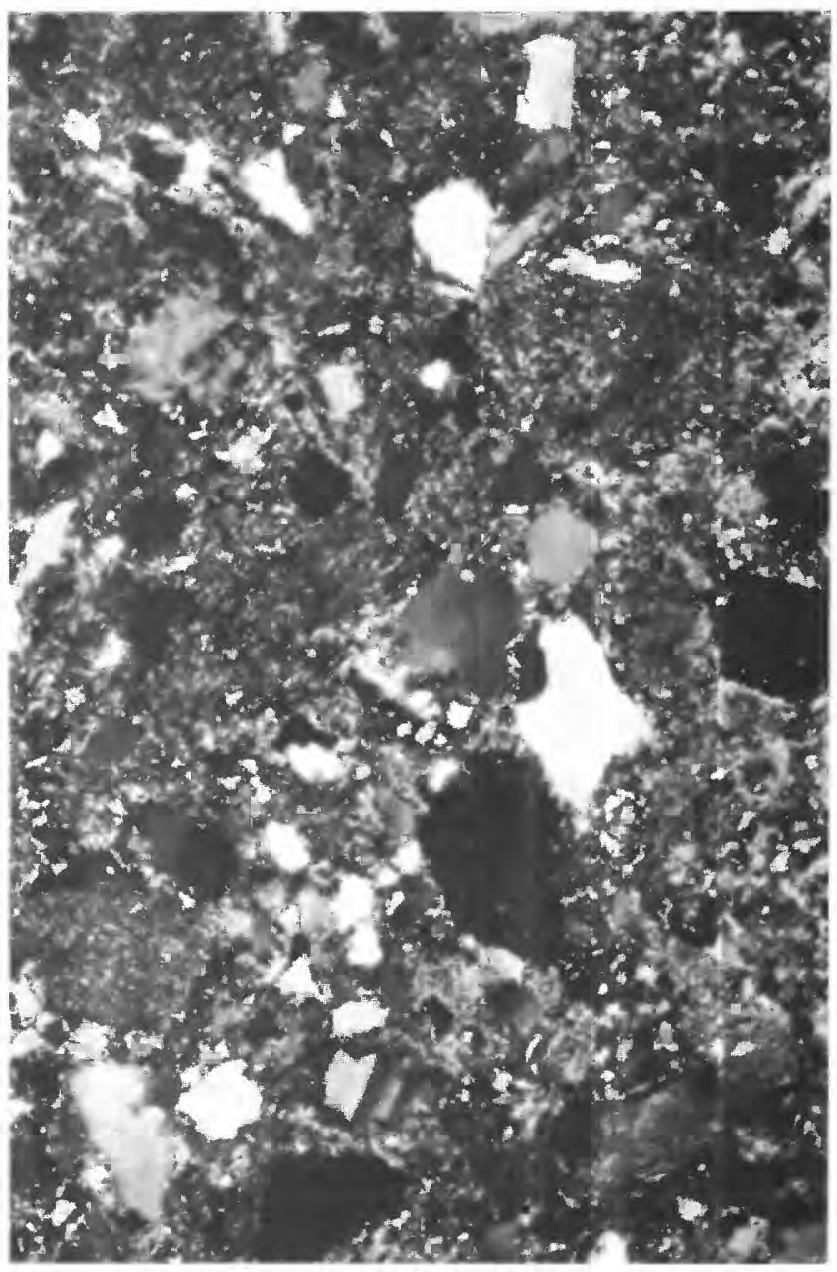

Figure 10. Photomicrograph of graywacke of Michigamme Formation showing abundance of felsic volcanic rock fragments, as at upper right and lower left. A more mafic chloritized (greenstone) volcanic rock fragment is dark grain near center. Microcline grain at lower middle right and altered feldspar at upper left. Field of view about $1.8 \mathrm{~mm}$ wide. Sample 86-MI-12B from Falls River just west of town of L'Anse.

potassium feldspar-quartz average 6.8 percent of the grains. Metamorphic rock fragments (argillite-slate-schist) are present in small amounts in five northern samples and six southern samples; in tables 2 and 3, polycrystalline quartz grains (recrystallized and sutured types) are listed as metamorphic rock fragments, and these grains constitute the majority of this component.

Five modal analyses of the basal Proterozoic (Goodrich) quartzites are included in table 2 and on the triangle of figure 8. A representative microscopic field of view is shown in figure 12.

\section{CHEMISTRY}

Major element analyses are sparse for the Michigamme Formation. The most complete chemical data are given by 


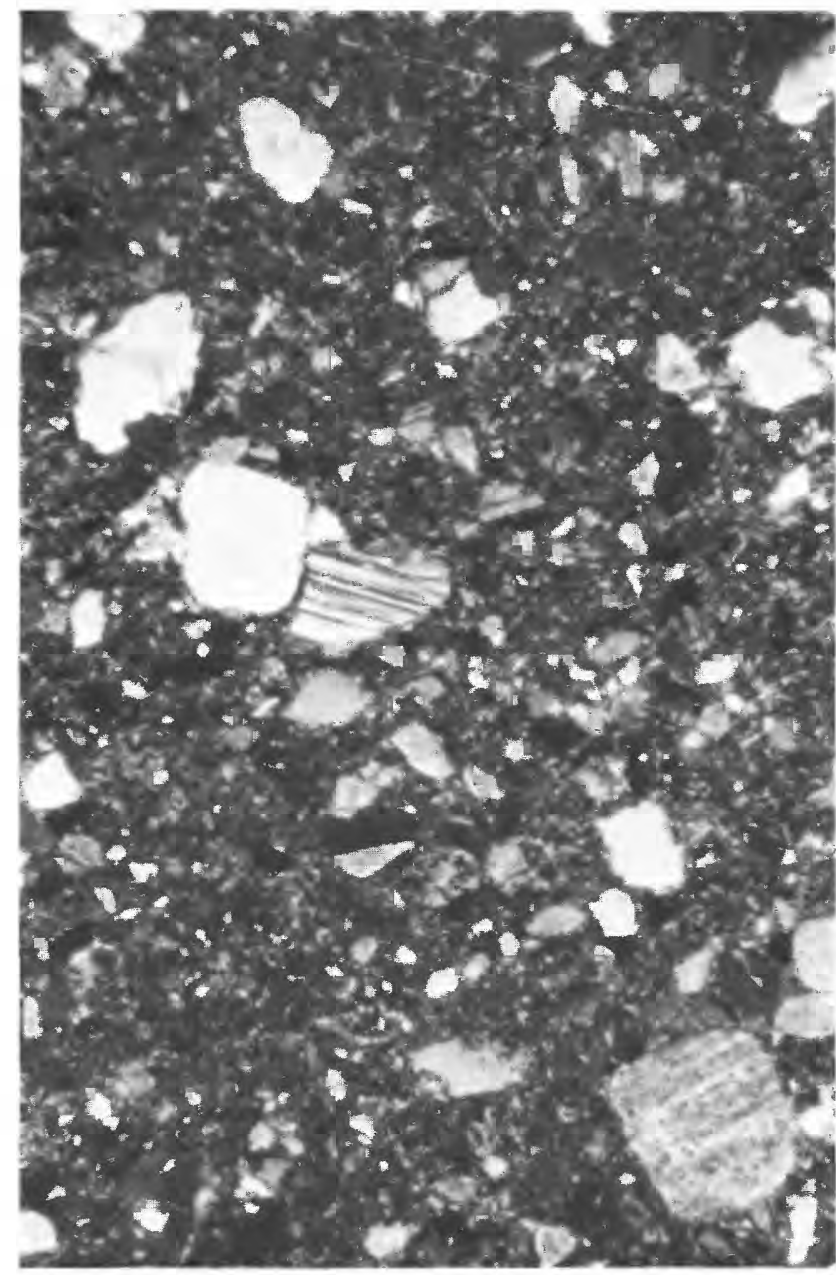

Figure 11. Photomicrograph of graywacke of Michigamme Formation showing fresh plagioclase (center) and altered plagioclase (lower right). Other sand- and silt-sized grains are quartz and feldspar. Field of view about $1.8 \mathrm{~mm}$ wide. Sample 78-M-141B from roadcut on U.S. Highway 141 about $8 \mathrm{~km}$ south of town of Covington.

Sims and others (1984) for samples from the area of Watersmeet (fig. 3); six of their Michigamme analyses are included with a few others in table 4.

The CIA (chemical index of alteration) of Nesbitt and Young (1982) can be used to indicate the weathering history of a sediment. For example, it can be used to determine whether a graywacke-mudstone sequence had a direct volcanic origin or is derived from a weathered volcanic terrane. (See Bailes, 1980; Ojakangas, 1986.) The indices for the Michigamme and related samples (all from the southern outcrop area of the Michigamme) range from 49.2 to 71.3 (table 4), perhaps indicating considerable variation in the amount of chemical weathering in the source areas, assuming the samples have not undergone chemical alteration during diagenesis, metamorphism, and (or) recent weathering. However, the CIA values undoubtedly also vary with grain

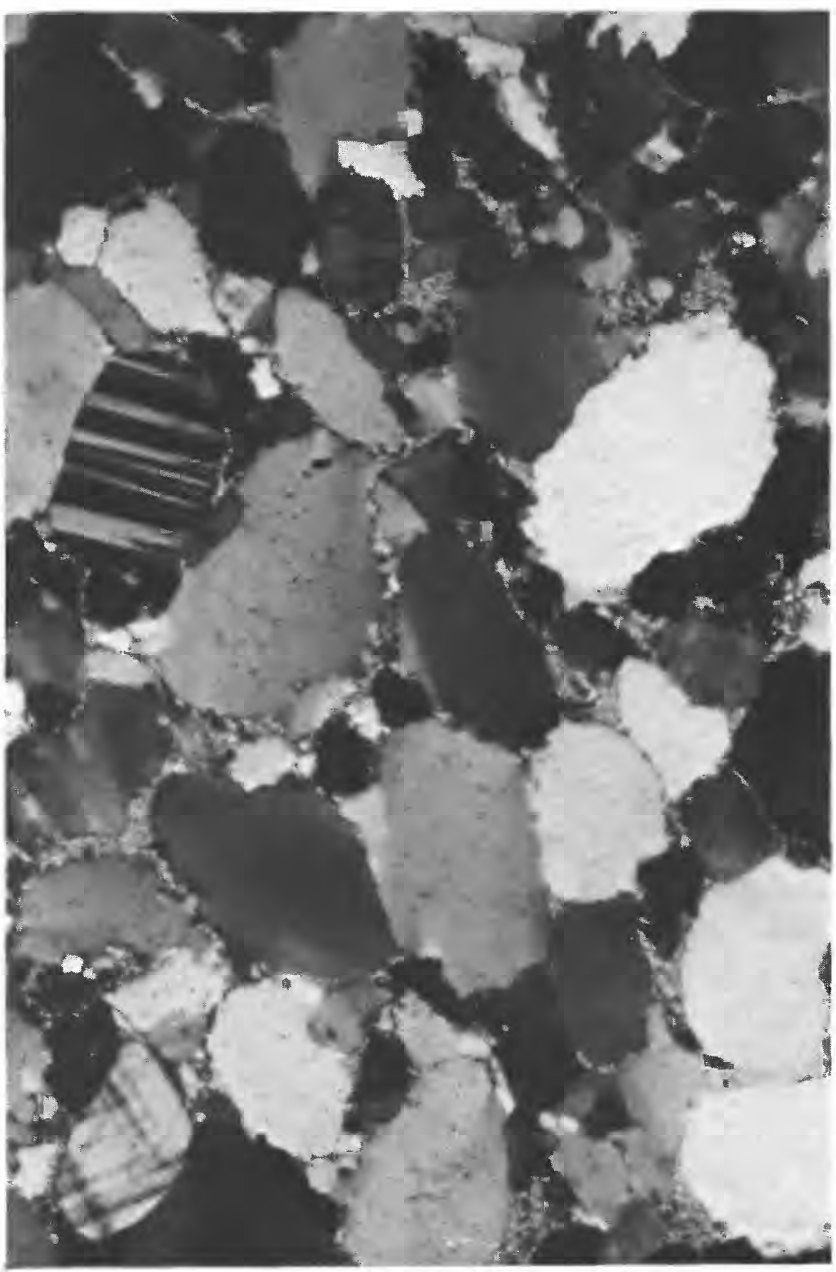

Figure 12. Photomicrograph of Goodrich Quartzite. Composed mostly of rounded quartz grains. Fresh plagioclase at upper left; fresh microcline at lower left. Minor silica cement and sericite matrix. Field of view about $1.8 \mathrm{~mm}$ wide. Sample from Arvon Hill about $17.7 \mathrm{~km}$ east-northeast of town of L'Anse.

size: those with more original clayey matrix should have higher amounts of $\mathrm{Na}_{2} \mathrm{O}$ and $\mathrm{K}_{2} \mathrm{O}$ and hence lower CIA values.

As for the northern exposures of the Michigamme, no samples were available for chemical analyses, except for 5ft composite samples from drill holes (table 5), which were analyzed. These samples are included here even with their composite nature, and the analyses were used for the calculation of the CIA index because of their low $\mathrm{CaO}$ values. They indicate a lack of diagenetic or metamorphic calcite.

The Badwater Greenstone and the Hemlock Formation, both bimodal volcanic units within the Baraga Group (Cannon and Klasner, 1975), have compositions similar to that of continental and oceanic basalts (Schulz, 1983, 1984). Schulz interpreted these rocks as indicating a rift environment, comparable to volcanic rocks in the Keweenawan 
Table 4. Chemical analyses of samples from southern exposures of Michigamme Formation

[CIA, chemical index of alteration]

\begin{tabular}{lrrrrrrrrr}
\hline Sample-- & \multicolumn{1}{c}{1} & \multicolumn{1}{c}{3} & \multicolumn{1}{c}{4} & \multicolumn{1}{c}{5} & 6 & 7 & 8 & 9 \\
\hline $\mathrm{SiO}_{2}$ & 57.94 & 60.03 & 58.03 & 63.2 & 58.5 & 67.6 & 60.1 & 63.3 & 66.4 \\
$\mathrm{Al}_{2} \mathrm{O}_{3}$ & 18.88 & 17.85 & 15.00 & 16.4 & 16.4 & 14.6 & 16.0 & 16.8 & 14.9 \\
$\mathrm{Fe}_{2} \mathrm{O}_{3}$ & 1.26 & 1.14 & 3.67 & 1.2 & .33 & .61 & 2.0 & 1.3 & .82 \\
$\mathrm{FeO}$ & 6.73 & 7.16 & 5.82 & 3.7 & 9.3 & 6.0 & 7.1 & 5.9 & 5.4 \\
$\mathrm{MgO}$ & 3.21 & 3.15 & 1.64 & 1.6 & 3.0 & 2.4 & 3.0 & 2.7 & 2.3 \\
$\mathrm{CaO}$ & .91 & .44 & .26 & 3.9 & 2.0 & 1.8 & 2.9 & 1.9 & 1.7 \\
$\mathrm{Na}_{2} \mathrm{O}$ & 1.69 & 1.64 & 3.52 & 4.4 & 3.1 & 3.4 & 2.8 & 3.4 & 4.6 \\
$\mathrm{~K}_{2} \mathrm{O}$ & 3.45 & 3.41 & 3.60 & 2.4 & 2.0 & 1.5 & 1.9 & 2.6 & .51 \\
$\mathrm{H}_{2} \mathrm{O}$ & 3.93 & 3.74 & 4.30 & 1.06 & 2.85 & 1.85 & 1.77 & 1.96 & 2.07 \\
$\mathrm{TiO}_{2}$ & .92 & .95 & .64 & .70 & .87 & .70 & .85 & .79 & .70 \\
$\mathrm{P}_{2} \mathrm{O}_{5}$ & .22 & .09 & .16 & .24 & .14 & .13 & .13 & .19 & .12 \\
$\mathrm{MnO}$ & .07 & .03 & .09 & .06 & .06 & .04 & .09 & .03 & .03 \\
$\mathrm{CO}_{2}$ & .06 & .12 & .03 & .02 & .08 & .02 & .08 & .01 & .02 \\
$\mathrm{CIA}$ & 69.8 & 71.3 & 59.6 & 49.2 & 60.1 & 58.2 & 57.2 & 58.6 & 57.0 \\
& & & & & & & & &
\end{tabular}

\section{SAMPLE DESCRIPTIONS}

1. Nanz, 1953, table 1, analysis 8, roadcut U.S. Highway 141 , about $10 \mathrm{~km} \mathrm{S.} \mathrm{of} \mathrm{Covington.}$

2. Nanz, 1953, table 1, analysis 9 , roadcut U.S. Highway 141 , about $5 \mathrm{~km} \mathrm{~S}$. of Covington.

3. Nanz, 1953, table 1, analysis 33, slate from footwall strata of Crystal Falls district, sec. 8, T. 42 N., R. 32 W.

4. Sims and others, 1984, table 7, sample No. D2433, Marenisco-Watersmeet area.

5-9. Sims and others, 1984, table 7, sample Nos. D2434, D2435, D2436, D2437, and D2440, respectively.

Midcontinent rift system and the Triassic basins of eastern United States.

Neodymium isotopic data (Barovich and others, 1989) from three northern samples and four southern samples of Michigamme Formation (the former presumably from the lower member of the Michigamme Formation and the latter presumably from the upper member of the formation) have been interpreted by Barovich and others to indicate that the northern samples had an Archean source $(\varepsilon \mathrm{Nd}(\mathrm{t})$ values from -10.8 to -6.6 ) and that the southern samples had an Early Proterozoic source $(\varepsilon \mathrm{Nd}(\mathrm{T})$ values from -0.9 to +1.3). However, the designation of all three northern samples as being from the lower member is likely erroneous. Sample 5 of Barovich and others (1989) (sec. 8, T. 47 N., R. 27 W.), taken from west of Ishpeming, is indeed from the lower member, but their sample 6 (sec. 9, T. 50 N., R. 33 W.), taken from Little Mountain, may have come from a thrust block (Klasner and others, 1991); if so, its original stratigraphic position within the Michigamme Formation is uncertain. Their sample 7 (sec. 26, T. 51 N., R. $32 \mathrm{~W}$.) is from the Silver River Falls locality at the west end of the East Baraga basin. Inasmuch as drill holes DL-1, DL-3, and DL-7, as well as DDH-116 (Burns, 1975), all from the East Baraga basin (fig. 3), contain only the upper member of the Michigamme (deposited upon iron-formation), the lower member is absent. Accordingly, their sample 7 is likely to come from the upper member of the Michigamme rather than the lower member of the Michigamme. Similar stratigraphic conclusions were reached by Trow $(1979$, p. 21$)$. 
Table 5. Chemical analyses of samples from northern exposures of Michigamme Formation (drill cores)

\begin{tabular}{lrrrrrrrrr}
\hline Sample -- & 1 & 2 & 3 & 4 & 5 & 6 & 7 & 8 & 9 \\
\hline $\mathrm{SiO}_{2}$ & 60.4 & 65.2 & 67.9 & 64.7 & 61.0 & 64.7 & 65.8 & 57.9 & 62.2 \\
$\mathrm{Al}_{2} \mathrm{O}_{3}$ & 18.9 & 16.9 & 16.3 & 16.7 & 19.8 & 15.1 & 15.8 & 21.5 & 18.0 \\
$\mathrm{Fe}_{2} \mathrm{O}_{3}$ & 8.55 & 9.21 & 6.04 & 7.92 & 8.16 & 6.75 & 7.53 & 7.04 & 8.08 \\
$\mathrm{MgO}$ & 3.33 & 3.10 & 2.86 & 3.07 & 2.65 & 3.12 & 3.86 & 3.32 & 3.19 \\
$\mathrm{CaO}$ & .40 & .32 & .66 & .22 & .23 & .77 & .40 & .27 & .71 \\
$\mathrm{Na}_{2} \mathrm{O}$ & 1.55 & 2.62 & 2.28 & 2.42 & .82 & 3.44 & .62 & 1.43 & 3.22 \\
$\mathrm{~K}_{2} \mathrm{O}$ & 4.07 & 2.82 & 3.26 & 2.69 & 5.01 & 1.58 & 3.08 & 5.20 & 2.66 \\
$\mathrm{TiO}_{2}$ & .84 & .77 & .66 & .69 & .73 & .61 & .53 & .69 & .78 \\
$\mathrm{P}_{2} \mathrm{O}_{5}$ & .11 & .10 & .11 & .02 & .03 & .11 & .04 & .12 & .11 \\
$\mathrm{MnO}$ & .04 & .03 & .03 & .03 & .02 & .05 & .04 & .03 & .06 \\
$\mathrm{CIA}$ & 71.1 & 68.0 & 65.8 & 69.6 & 73.3 & 63.2 & 75.7 & 71.7 & 65.6 \\
& & & & & & & & & \\
\hline
\end{tabular}

\section{SAMPLE DESCRIPTIONS}

1. Trow, 1979, Appendix, sample 1-224-229, p. 96, $5 \mathrm{ft}$ composite, Hole DL-1, East Baraga basin.

2. Trow, 1979, Appendix, sample 1-1244-1249.

3. Trow, 1979, Appendix, sample 3-504-509, p. 97, $5 \mathrm{ft}$ composite, Hole DL-3, East Baraga basin.

4. Trow, 1979, Appendix, sample 3-1314-1319.

5. Trow, 1979, Appendix, sample 5-454-459, p. 98, $5 \mathrm{ft}$ composite, Hole DL-5, Clark Creek basin.

6. Trow, 1979, Appendix, sample 4-709-714, p. 99, $5 \mathrm{ft}$ composite, Hole DL-4, Dead River basin.

7-9. Trow, 1979, Appendix, samples 4-1069-1074, 1-2059-2064, 4-2239-2244, respectively.

Therefore, the conclusion of Barovich and others (1989) that the lower part of the Marquette Range Supergroup had an Archean source and the upper member of the Michigamme Formation had an Early Proterozoic source needs some modification. One and possibly two of the samples from the northern Michigamme are stratigraphically from the upper member of the Michigamme; therefore, both the lower part of the Marquette Range Supergroup and the upper member of the Michigamme Formation in the northern outcrop area had Archean sources. Furthermore, the tectonic scenario is so complicated (Gregg, 1993) that some of the samples from the southern Michigamme of Barovich and others (1989) could be upthrusted lower Michigamme rather than upper Michigamme. The available data indicate that the northern samples had an Archean source and the southern samples had an Early Proterozoic (southern) source, regardless of stratigraphic position within the Marquette Range Supergroup. However, it would be desirable to have a larger Michigamme Nd data base.

\section{PALEOCURRENT ANALYSIS}

\section{Metagraywacke and Metasiltstone}

Paleocurrent indicators are uncommon in the metagraywacke beds of the Michigamme Formation, and only 51 paleocurrent features were measured (fig. 13). A total of 15 sole marks was measured; 7 of these are flute casts (scour marks) and 8 are various elongate sole marks, mostly groove casts and scour channels. The bottoms (soles) of most beds are very flat and featureless, except for cleavage-bedding intersections that have produced abundant "pseudo-sole marks."

A few small-scale crossbeds were measured in the $C$ intervals of Bouma A-B-C beds. Small-scale crossbedding in thin metasiltstone-slate sequences found between thicker metagraywacke beds provided most of the 35 crossbed measurements; such metasiltstone beds could be distal parts of turbidite beds (Bouma $\mathrm{C}$ beds). One low-relief scoured channel was also measured. 

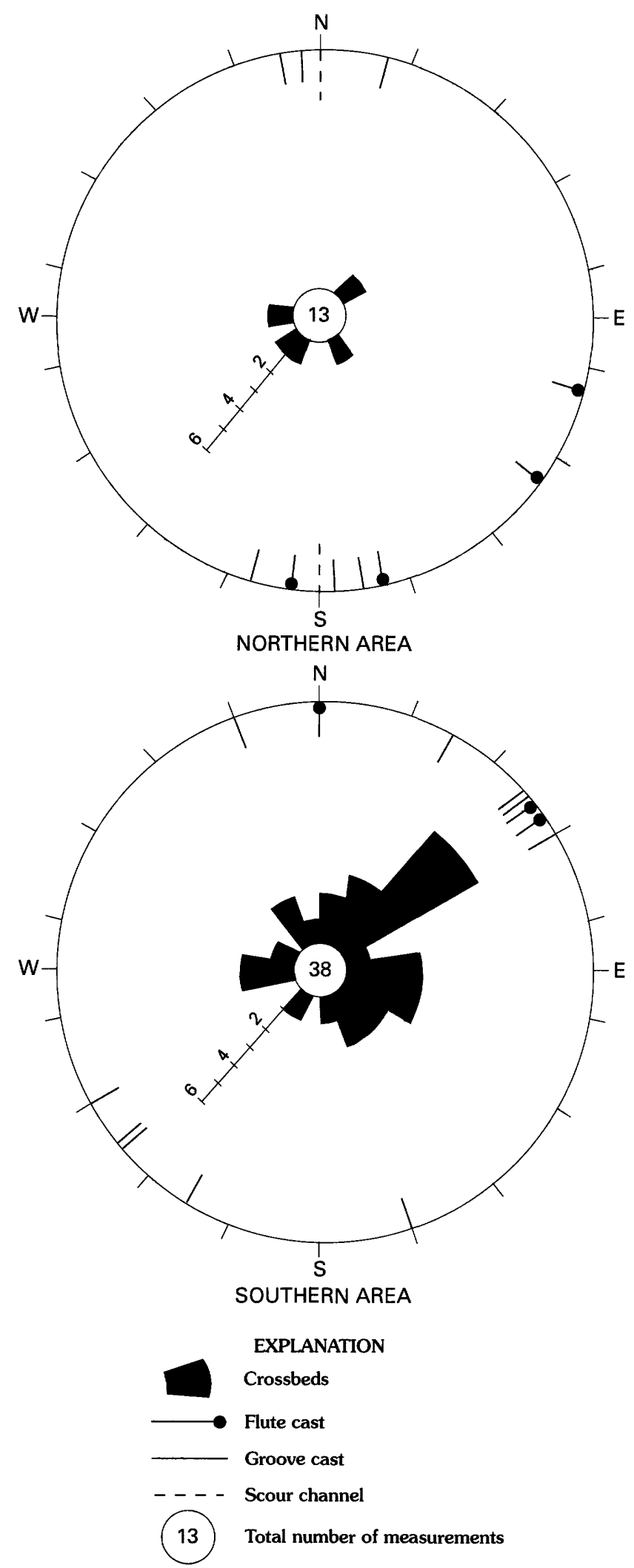

Figure 13. Paleocurrent plots of measurements in graywackeslate units of northern and southern exposures of the Michigamme Formation. Note that groove casts and scoured channels are plotted on both sides of diagrams, as they do not indicate a unique current sense.
Of the 51 measurements, 13 are from four outcrop areas in the northern part of the study area, and 38 are from six outcrop areas in the southern part of the study area; Covington is the approximate east-west dividing line (fig. 3). The paleocurrent plots for the northern and southern parts of the study area are summarized in figure 13.

Locations of outcrops of Michigamme Formation from which paleocurrent measurements were obtained, plus types of measured sedimentary structures, are as follows:

"Northern area" outcrops:

1. Silver River Falls area, NW corner sec. 26, T. 51 N., R. $32 \mathrm{~W}$. (two crossbeds and two flute casts).

2. Falls River, upstream from Highway 28 bridge at L'Anse, sec. 9, T. 50 N., R. 33 W. (one crossbed and two flute casts).

3. Slate River, south of bridge on road to Skanee, C W. edge sec. 9, T. 51 N., R. 31 W. (two crossbeds).

4. Tibbett's Falls on Sturgeon River, SW1/4 sec. 5, T. 48 N., R. 34 W. (one flute cast, two groove casts, and one channel scour).

"Southern area" outcrops:

1. Roadcuts on Highway 141, south of Covington, $\mathrm{NW}^{1} 1 / 4 \mathrm{SE}^{1 / 4} \mathrm{sec} .36, \mathrm{~T} .47 \mathrm{~N}$., R. $34 \mathrm{~W}$. (six crossbeds, one flute cast, and one groove cast).

2. Roadcuts on Highway 141, south of Covington, W $1 / 2$ NW $1 / 4$ sec. 12 , T. 47 N., R. 34 W. (one flute cast and three groove casts).

3. Roadcut on Highway 141, just south of railroad tracks in Covington (two crossbeds).

4. Roadcut, C S1/2 sec. 16 , T. 46 N., R. 35 W. (14 crossbeds).

5. Hemlock Rapids on Paint River, $\mathrm{SE}^{1 / 4} \mathrm{NE}^{1 / 4} \mathrm{sec} .23$, T. 44 N., R. 34 W. (one crossbed, one flute cast, and one groove cast).

6. Little Bull Rapids, dam area, on Paint River, $\mathrm{N} 1 / 2 \mathrm{SW}^{1} / 4$ sec. 24, T. 42 N., R. 32 W. (seven crossbeds).

For each outcrop from which measurements were made, the master bedding was rotated back to a horizontal configuration around the strike of the beds. Only this one-tilt rotation was utilized, because the fold axes throughout most of the study area are subhorizontal or have only moderate plunges. Probable northward thrusting and multiple deformation in the region (Klasner and others, 1991; Gregg, 1993) may have affected the readings to some degree. In interpreting the measurements, this possible error should be borne in mind. Also, the total number of measurements is obviously too small for statistical analysis.

The correlative Copps Formation between Lake Gogebic and Wakefield (fig. 3) yielded only 11 paleocurrent measurements; 9 are small-scale crossbeds (mostly in siltstone beds, but a few are from the $\mathrm{C}$ interval of Bouma beds), and 2 are sole marks (flute casts). The paleocurrent plot gives a very broad paleocurrent trend to the west, north, and east (fig. 14A). Lineations are problematical in the Copps outcrop 


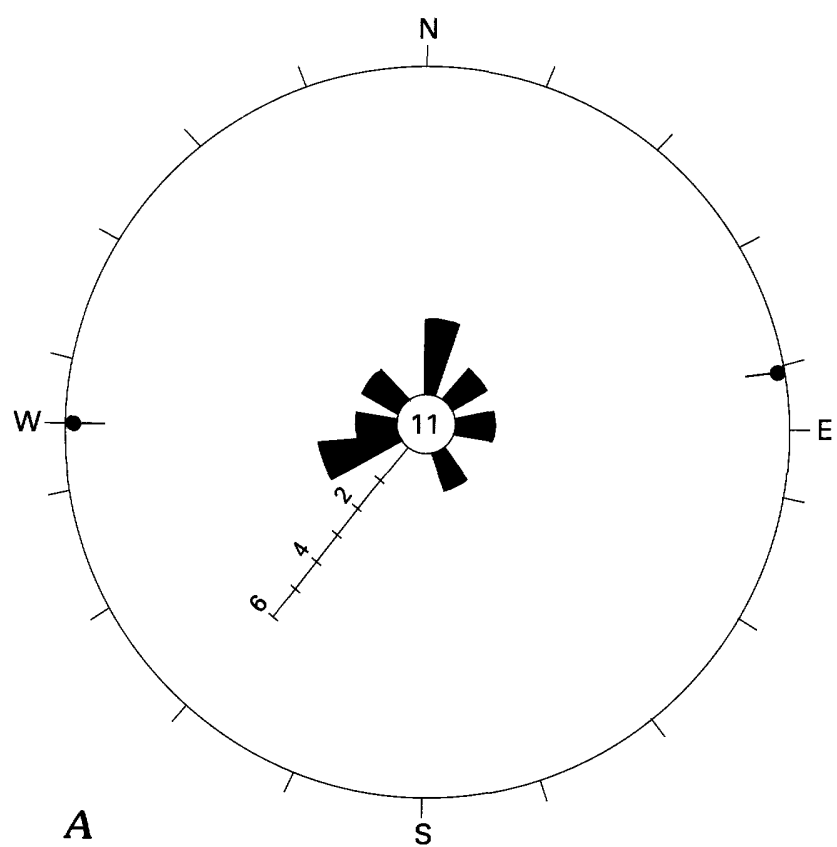

COPPS FORMATION

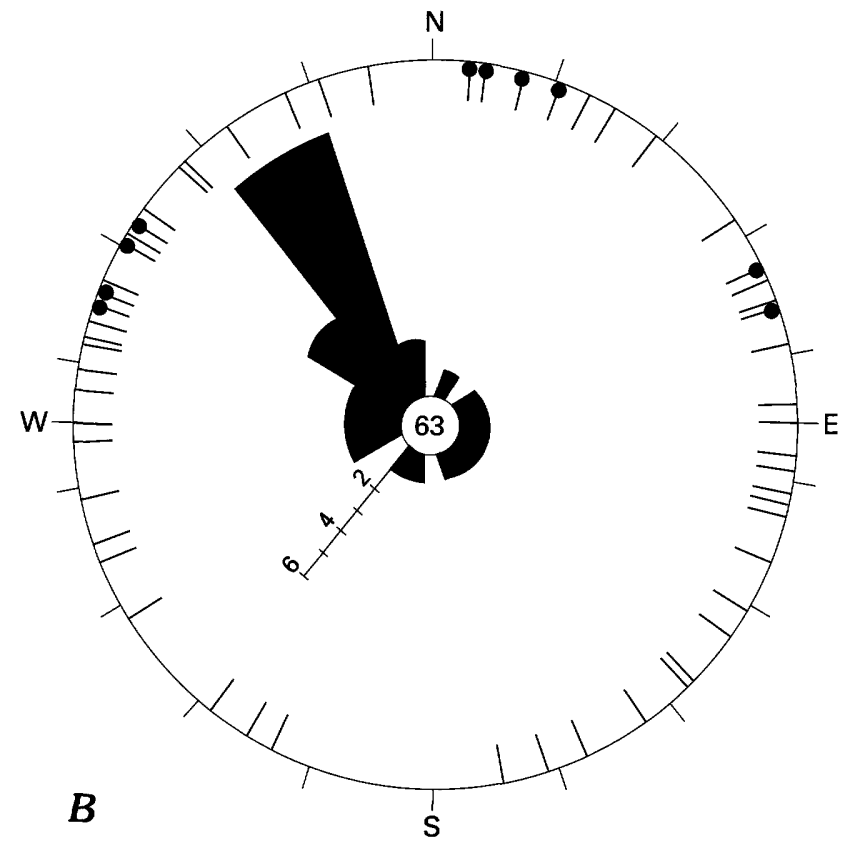

TYLER FORMATION

EXPLANATION

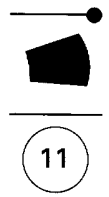

Flute cast

Crossbeds

Groove cast

Total number of measurements

Figure 14. Paleocurrent plots of measurements in $A$, Copps Formation, and $B$, Tyler Formation. (Data on Tyler Formation from Alwin, 1976.) area, so the effect of folding is unknown; however, only a one-tilt correction was applied to the data.

In a study of the correlative Tyler Formation on the Gogebic range (fig. 3), Alwin (1976) found a prominent northwestward paleocurrent trend (fig. 14). Lineations in the Tyler are generally subhorizontal so only a single tilt correction was deemed necessary. It is possible that the Tyler Formation was thrust northward and that the Tyler outcrop belt is allochthonous (Klasner and others, 1991). Nevertheless, I assume that the Tyler behaved as a block and that the paleocurrent indicators were not rotated relative to each other, nor was the entire block rotated either clockwise or counterclockwise.

In summary, the measurements from the metagraywacke-metasiltstone-slate sequences of the Michigamme and correlative formations have an apparent dominant southerly trend in the northern outcrop areas and an apparent dominant northerly trend in the southerly areas, as shown in figure 15 . The paleocurrent data of figure 13 are generalized in figure 15 , with all the measurements plotted on two rose diagrams. The total numbers of measurements in the northern and southern areas (only 13 and 38, respectively) are small; nevertheless, fairly strong unimodal patterns are evident.

\section{Goodrich Quartzite}

Paleocurrent indicators in the gently dipping basal quartzite beds of the exposed Early Proterozoic succession, considered as Goodrich Quartzite by Cannon (1986) and by me, were measured at four localities near the west end of the Archean northern complex. Figure 16 shows detailed paleocurrent plots-divided out by sedimentary structurefrom these four localities, and figure 17 is a map showing the localities and generalized data-combined into one rose diagram per locality.

At Canyon Falls on the Sturgeon River, the southernmost of the four quartzite localities, the pattern indicates that currents were toward the north, west, and south (based on 24 measurements). Parallel beds as much as $30 \mathrm{~cm}$ thick dominate at this locality, but planar crossbeds as much as 8 $\mathrm{cm}$ thick and trough crossbeds as much as $20 \mathrm{~cm}$ thick are present. Very fine mud drapes (flaser bedding) are rare. At the "Near Canyon Falls" locality, about $1.6 \mathrm{~km}$ north-northeast of Canyon Falls, the pattern $(n=17)$ is similar; currents were to the southwest and northwest, both trough and planar crossbeds are present; troughs are as much as $2 \mathrm{~m}$ wide and crossbed sets are $10-50 \mathrm{~cm}$ thick.

At Pike's Peak, about $25 \mathrm{~km}$ north-northeast of Canyon Falls, feldspathic quartzite and conglomerate of the Goodrich contain trough-type crossbeds; troughs are on the scale of $1 \mathrm{~m}$ wide and crossbed sets are $15-30 \mathrm{~cm}$ thick. The paleocurrent pattern $(n=20)$ is toward the northwest. 


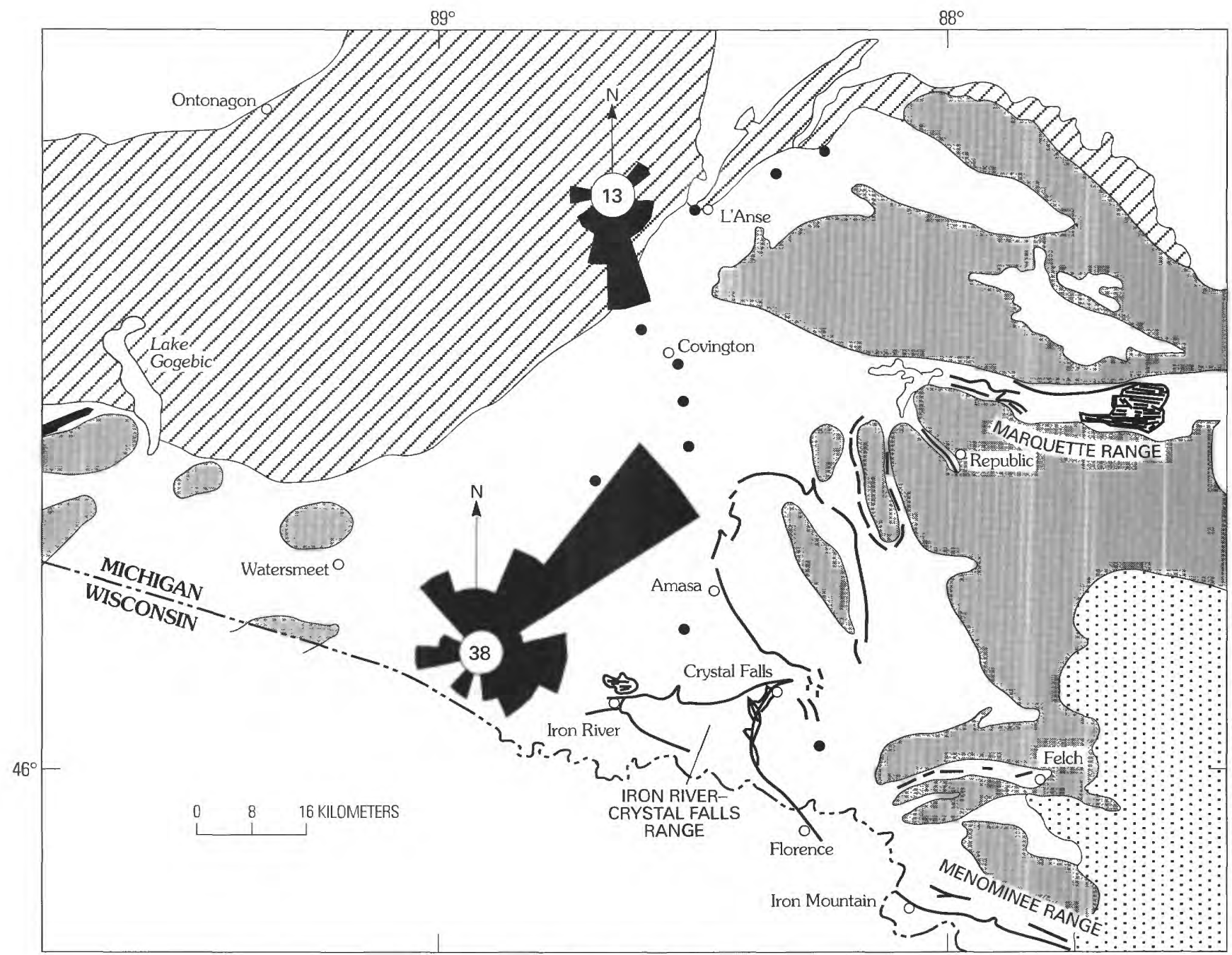

EXPLANATION

Paleozoic rocks
Rocks of Marquette Range Supergroup
(Early Proterozoic)-Mostly Michigamme Formation.
Heavy black lines and areas, iron-formation

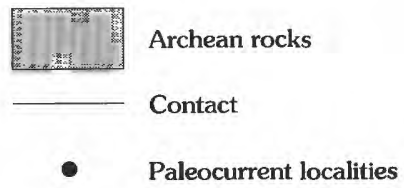

Figure 15. Interpretive plot of paleocurrent data (shaded area) of Michigamme Formation graywackes shown in figure 13. Replotted onto northern and southern rose diagrams (combined with crossbed data) with flute casts, groove casts, and scour channels shown as single directions, even though the latter two types of sedimentary structures do not yield a unique current sense.

At Arvon Hill, about $10 \mathrm{~km}$ southeast of Pike's Peak, the pattern $(n=25)$ is strongly bimodal-bipolar, with currents toward both the northwest and the southeast. The crossbedding is trough-type; troughs range from $10 \mathrm{~cm}$ to $1 \mathrm{~m}$ wide and crossbed sets are $5-30 \mathrm{~cm}$ thick. A white quartzite, which apparently dips outward from the top of the small hill, passes upward into dark-gray quartzite and then into black metagraywacke and slate.

In summary, the dominant paleocurrents in the Goodrich Quartzite flowed outward from the west end of the Archean northern complex, towards the southwest, west, and north.

\section{SEDIMENTATION}

\section{Introduction}

The Baraga Group, consisting of the Goodrich Quartzite and the Michigamme Formation in the western Marquette range (fig. 1), is the product of the third and final cycle of deposition in the Marquette Range Supergroup (Sims and others, 1981). The sedimentation of the lower slate member of the Michigamme Formation is closely related to the sedimentation of the underlying Goodrich Quartzite. This 


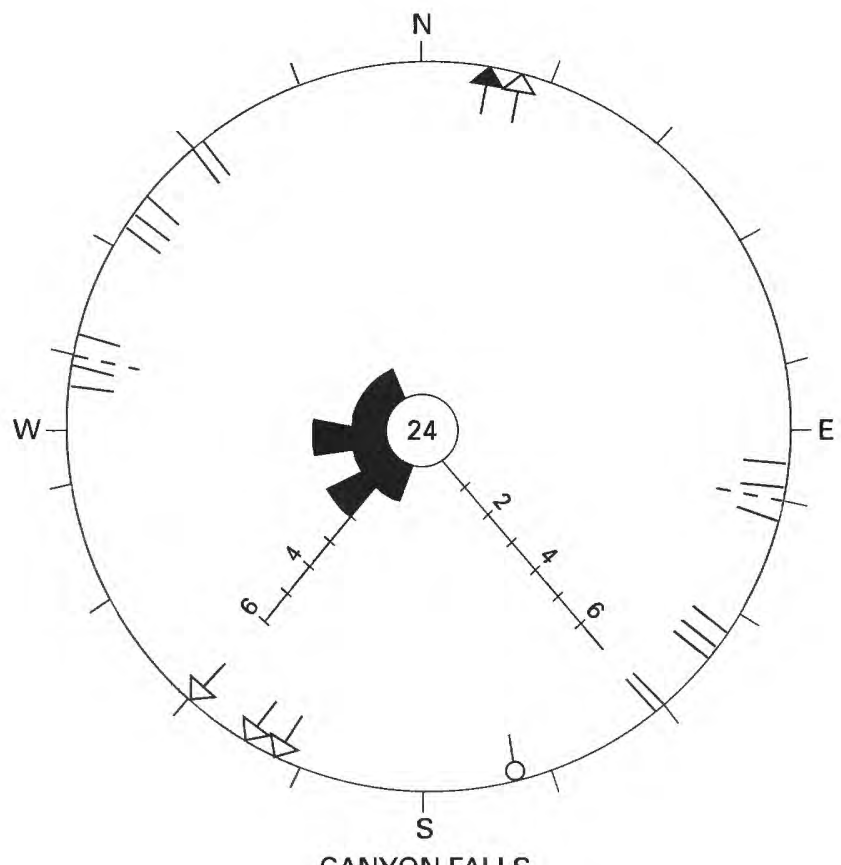

CANYON FALLS

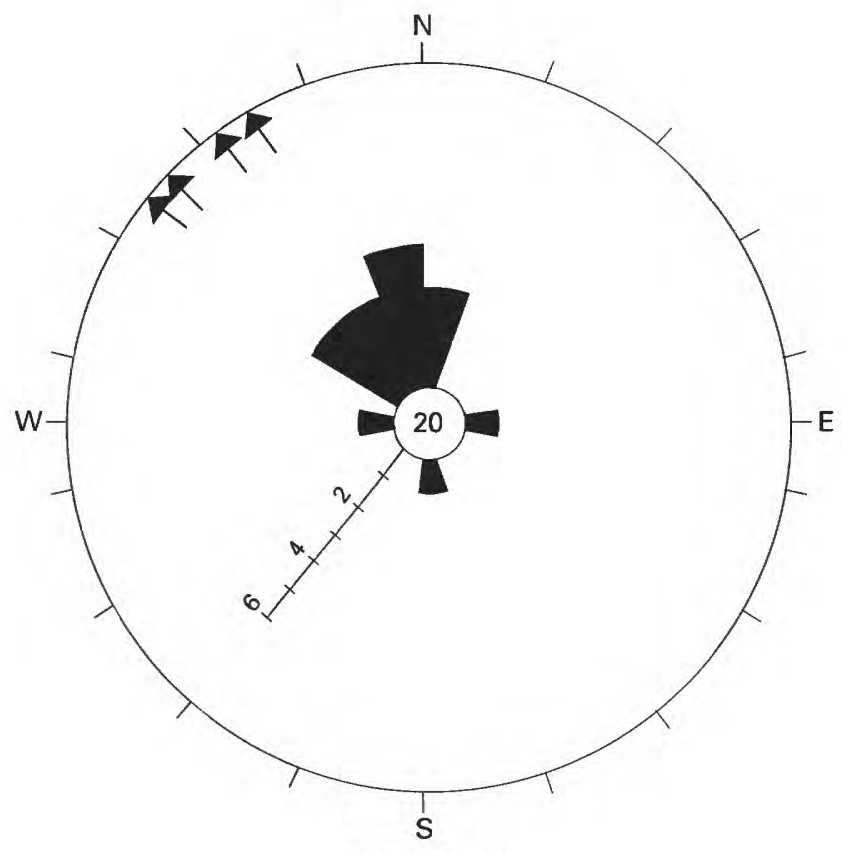

PIKE'S PEAK

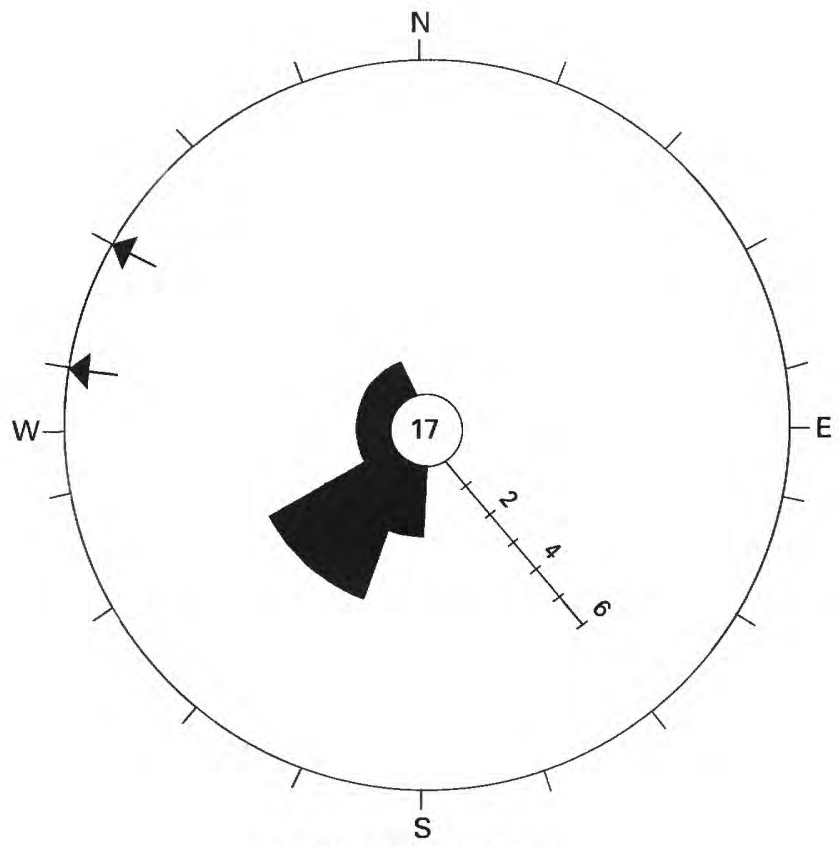

NEAR CANYON FALLS

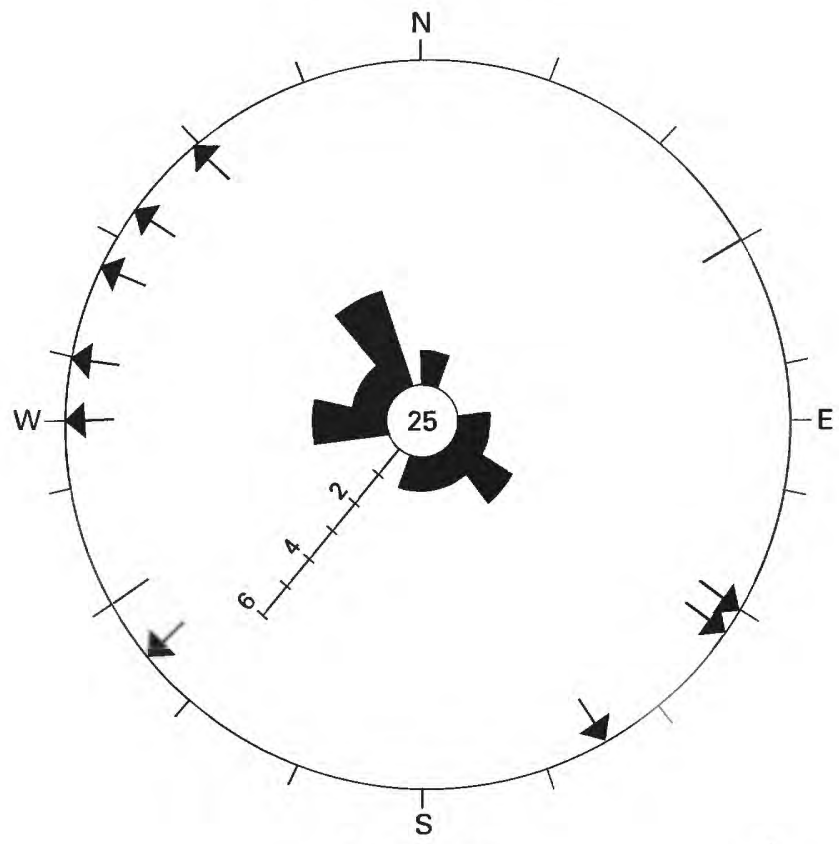

ARVON HILL

\section{EXPLANATION}
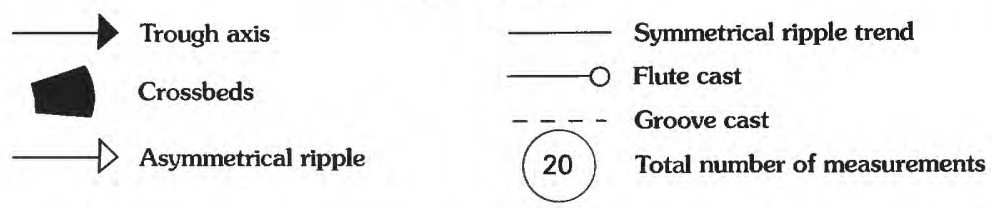

Figure 16. Paleocurrent plots of four outcrops of Goodrich Quartzite in northern Michigan. Localities shown and data generalized in figure 17. Canyon Falls, C S. edge sec. 19, T. 49 N., R. 33 W.; "Near Canyon Falls," SW. cor. sec. 17, T. 49 N., R. 33 W.; Pike's Peak, C and E1/2 sec. 11, T. 51 N., R. 32 W.; Arvon Hill, C sec. 28, T. 51 N., R. 31 W. 


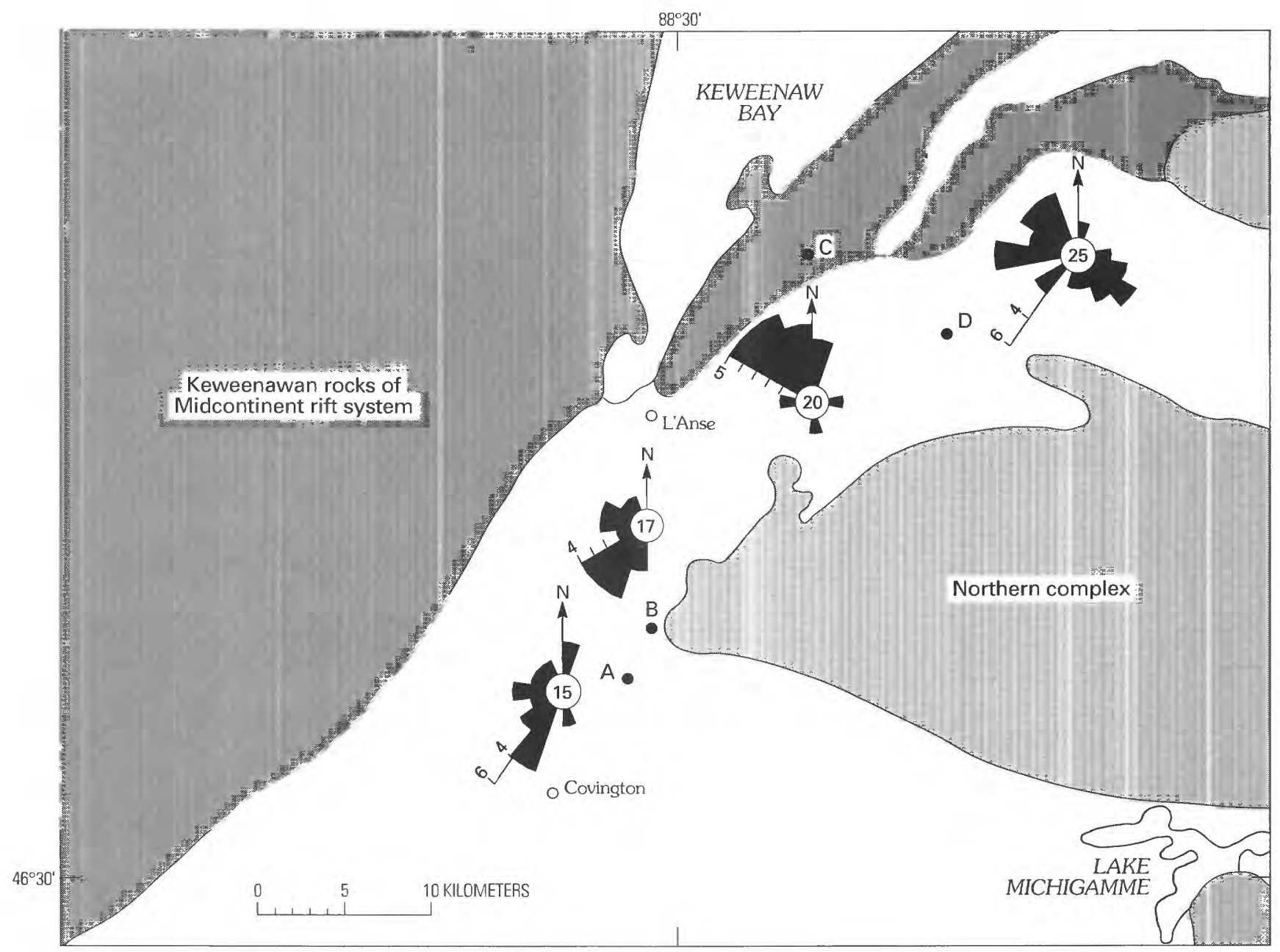

Figure 17. Locations of four outcrops of Goodrich Quartzite near west end of the Archean northern complex. Paleocurrent plots are generalized from figure 16 to interpret direction, but symmetrical ripple trends and the lone groove cast were not plotted on rose diagram A. A, Canyon Falls; B, "Near Canyon Falls"; C, Pike's Peak; D, Arvon Hill.

relationship is most evident in drill holes DL -4 (Dead River Basin) and DL-5 (Clark River Basin), where the quartzite and graywacke units are gradational. In outcrops in the Negaunee SW $71 / 2^{\prime}$ quadrangle (Clark and others, 1975) and the Negaunee $71 / 2^{\prime}$ quadrangle (Puffett, 1974), the Goodrich Quartzite (not formally named by Puffett, 1974) is overlain by the lowermost Michigamme unit, an "interbedded finegrained quartzite and siltstone" that becomes finer grained upward; in turn this rock is overlain by iron-formation and graywacke-slate. As outlined following, the sequence indicates changes upward from a shallow-water environment (the Goodrich and lower member of the Michigamme) to a transitional somewhat deeper water environment in which the Bijiki Iron-formation Member was deposited below wave base, and finally to a still deeper water environment in which turbidity-current deposition was intermittently imposed into a regime of slow suspension settling of fine particles (upper member of the Michigamme). This interpretation is slightly at variance with Cannon and Klasner's
(1977) interpretation that the lower member of the Michigamme, the Bijiki, and the lower part of the upper member are relatively shallow water deposits, whereas the remainder of the upper member of the Michigamme is a deeper water turbidite deposit.

\section{Goodrich Quartzite}

The Goodrich Quartzite is the basal Proterozoic sedimentary unit in the area west and northwest of the Marquette syncline; it lies directly on Archean basement, commonly with an intervening regolith. The quartzite was studied at four localities on the west and northwest edges of the Archean northern complex (fig. 16), as well as in drill cores DL-4 and DL-5 (fig. 7). A detailed study of the Goodrich Quartzite in the Marquette syncline (to the east) was beyond the scope of this project.

The paleocurrent data at three localities are unimodal, radiating outward from the Archean basement complex 
toward the southwest, west, northwest, and north (fig. 17). At the fourth locality (Arvon Hill), the plot is bimodalbipolar with modes to the northwest and southeast (figs. 16, 17), an arrangement that can be interpreted as being the product of a tidal environment. The three unimodal plots, although not distinctly suggestive of a tidal influence, could nevertheless be tidal, formed under the influence of strong ebb tides. The mineralogical (table 2) and textural maturity of the sands in the basal quartzite unit also fit such an interpretation, as a tidal environment results in long and continued abrasion and maturation of sand (Klein, 1975, p. 50). Because the Goodrich is the basal Proterozoic unit in the area, it probably was deposited in a sea that transgressed onto a low-lying landmass of Archean rocks. This landmass stood above sea level and influenced tide- and wind-generated current systems. Because the Goodrich Quartzite is thin, it is likely that the landmass had little relief and therefore shed only a modest amount of sediment into the adjacent sea. A regional analog is the Early Proterozoic Palms Formation, the basal terrigenous clastic unit on the Gogebic range, $80-160 \mathrm{~km}$ to the west, which I have interpreted as the product of a tidally influenced nearshore environment in a transgressing sea (Ojakangas, 1983).

\section{Lower Slate Member, Michigamme Formation}

The lower slate member of the Michigamme, where it can be stratigraphically placed unequivocally above the Goodrich Quartzite and below the Bijiki Iron-formation Member, as in drill cores DL-4 and DL-5, consists of thin light-tan sandstone beds, similar to the sandstone of the underlying Goodrich, separated by thin dark shale partings (fig. 18). Also present are thin siltstone beds alternating with thin argillite beds. These lithologic variants are the products of alternating low-energy and higher energy conditions, typical of a tidally influenced environment. As noted just previously, the Palms Formation (middle member) on the Gogebic range is an analog.

\section{Bijiki Iron-formation Member, Michigamme Formation}

The Bijiki is very fine grained and thin bedded. Evidence is lacking for either high-energy or alternating low- and higher energy conditions, as in the lower member of the Michigamme. The overlying upper member, as interpreted following, has characteristics of a turbidite sequence deposited in relatively deep water. It seems likely that the iron minerals of the Bijiki were precipitated out of surface waters and settled into a low-energy environment below wave base in relatively deep water. On the Mesabi range in Minnesota (Ojakangas, 1983), a fine-grained and thin-bedded iron-formation facies (that is, lower and upper slaty members) is interpreted as a deeper water shelf deposit formed seaward

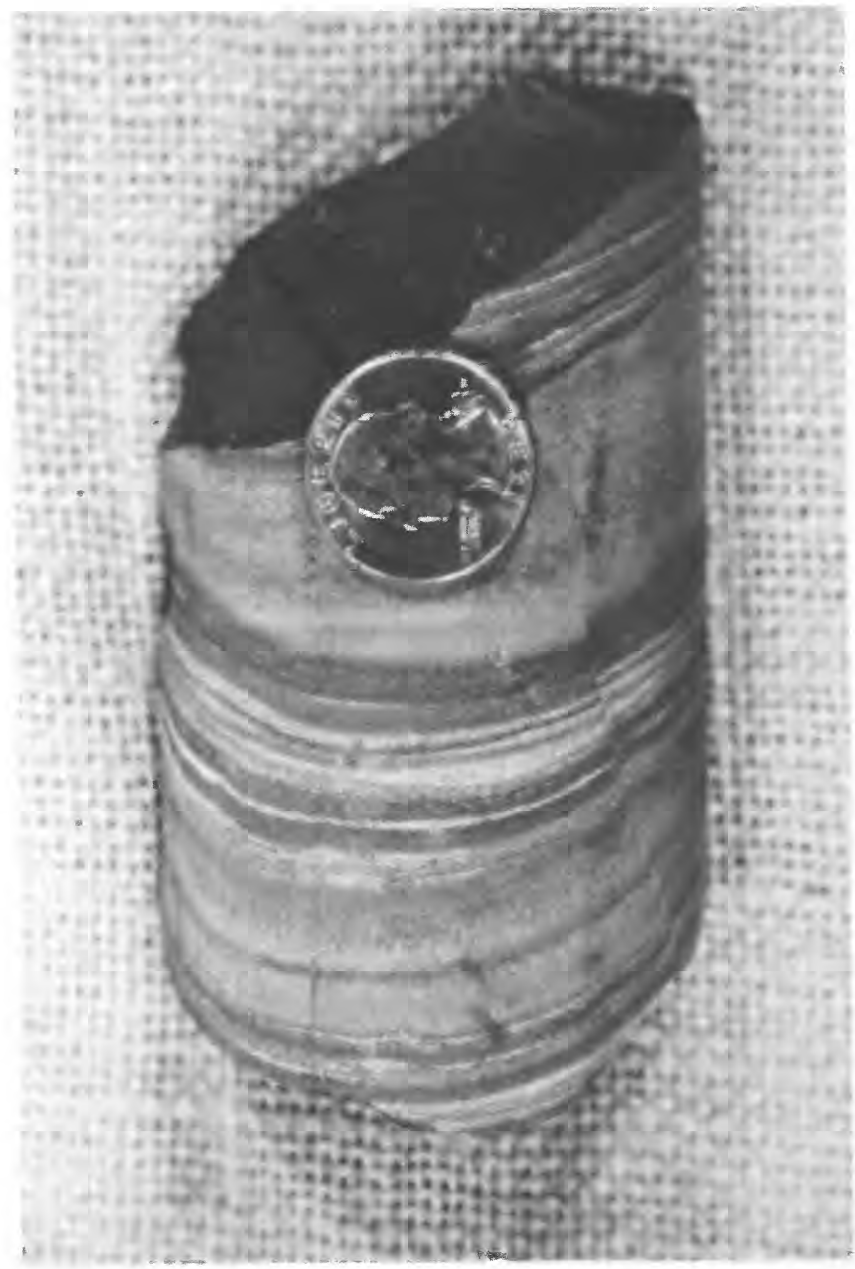

Figure 18. Part of drill core DL-5, showing lower slate member of Michigamme Formation. Footage is $845 \mathrm{ft}$, near the middle of the lower member. (Figure 7 describes drill core.) Stratigraphic tops are towards the top.

from a coarser grained and crossbedded facies (the lower and upper cherty members). If the structures logged as stromatolites in the cores (Trow, 1979) are indeed stromatolites rather than deformational features, they provide further support for a relatively shallow water regime of less than about $60 \mathrm{~m}$ depth, the depth of sunlight penetration. However, I think these structures are suspect (that is, deformational in origin), and that the water depth is indeterminant.

\section{Upper Slate Member, Michigamme Formation}

The graded graywacke beds in the upper member of the Michigamme are characteristic of deposition by turbidity currents. The dominant mudstones (now slates) between the graded beds would have been formed by the slow settling of fine-grained sediment (clay and silt) during the time intervals between turbidity currents. Deposition was below storm wave base, likely in relatively deep water, and possibly on 
or near submarine fans. The measured sections (table 1) reveal additional details on the sedimentation by turbidity currents. The graywacke beds are classic turbidites, with an apparent lateral continuity, good grading, and very flat soles.

In the 74-m-thick measured section at Little Bull Rapids (fig. 6) near Crystal Falls, 70 percent of the 63 graywacke beds are graded, and the proximality index of Walker (1967) is a high 86 , suggesting that the section is proximal to the originating point of the turbidity currents. The proximality index as used here in a generalized way is given by the percentage of graywacke beds starting with Bouma A plus one-half of the percentage of beds starting with Bouma B (Walker, 1967). The sequence in this measured section fits turbidite facies C, comprised of proximal turbidites (Walker and Mutti, 1973). Not shown in table 1 is the observation that the entire section is a crudely thinning upward and fining upward sequence, with the coarser beds in the lower twothirds of the section. Within this thinning-upward sequence, three thickening-upward sequences 2,4 , and $26 \mathrm{~m}$ thick can be distinguished, although as pointed out by Walker (1984, p. 183), such sequences can be "in the eyes of the beholder," depending upon which beds-thin or thick-are interpreted as the beginning of a sequence. This measured section may be interpreted as indicating either the shifting of a suprafan lobe or the filling and migration of a middle fan channel (Walker and Mutti, 1973; Walker, 1984).

Measured section II, on Ramsey Island in Lake Michigamme, near the west end of the Marquette syncline, consists of 14 thick, graded graywacke beds with a proximality index of 100. These are classical proximal turbidites of Walker (1967) and turbidite facies C of Walker and Mutti (1973) and Walker (1984). The short section could be interpreted as consisting of either a few thinning-upward sequences or a few thickening-upward sequences. The interpretation is the same as for measured section I.

Measured section III at Silver River Falls, east of L'Anse in the northernmost Michigamme exposures, contains much less graywacke than do sections I and II, and the beds are thinner and finer grained. Soles are very flat and sharp. This section fits turbidite facies $\mathrm{D}$, with pelagic mud dominant over graywacke. It appears to be a part of a distal turbidite sequence, deposited on the lower part of a fan or as a basin plain sequence.

The graywacke beds in the roadcuts along U.S. Highway 141 south of Covington (fig. 5) appear to be proximal turbidites of facies $\mathrm{C}$ and may belong to the middle fan lobe association.

In summary, the graywacke-siltstone-mudstone sequences, now metagraywacke-metasiltstone-slate sequences, appear on the basis of a few short measured sections and countless observations to be submarine fan deposits. Alternatively, they could be ramp deposits, laid down along the margins of a basin below a major break in slope, without the presence of submarine fans. The generally fine grain size, the general lack of sole marks, and the very

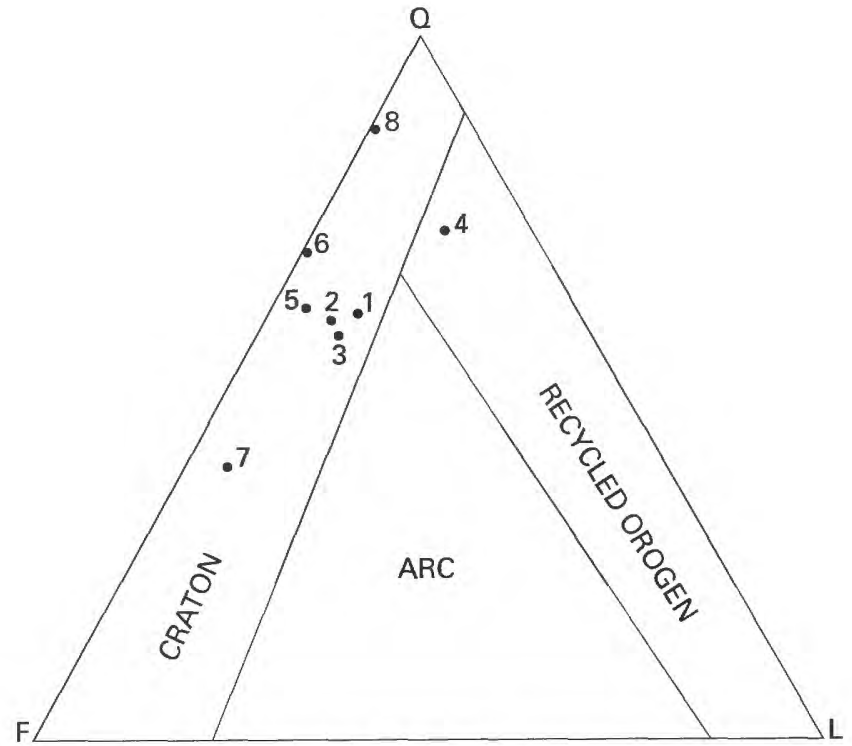

EXPLANATION

1 Northern exposures of Michigamme Formation

2 Southern exposures of Michigamme Formation

3 Copps Formation

4 Tyler Formation

5 Thomson Formation

6 Rove Formation

7 Virginia Formation

8 Goodrich Quartzite

Figure 19. Averages of modal analyses of graywackes from northern and southern outcrops of Michigamme Formation and the Copps, Tyler, Thomson, Rove, and Virginia Formations, as well as the Goodrich Quartzite, plotted on a $Q / F / L$ triangle depicting tectonic provenance. Triangle modified from Dickinson and others (1983). Note that the modes are probably considerably modified from what they were prior to diagenesis and metamorphism. Tyler average calculated from Alwin (1976); Rove average calculated from Morey (1967); Virginia average calculated from Lucente and Morey (1983); Thomson average calculated from Morey and Ojakangas (1970).

flat nature of the soles of graywacke beds over much of the area (measured sections I and II are exceptions) suggest that many beds were deposited on distal portions of fans or on an abyssal plain.

\section{TECTONIC MODEL AND PROVENANCE}

Sandstone compositions, when plotted on a $\mathrm{Q} / \mathrm{F} / \mathrm{L}$ triangle, can be assigned to tectonic source areas. A triangle utilized by Dickinson and others (1983) indicates three main source terranes for North American Phanerozoic sandstones-cratonal, recycled orogen, and magmatic arc. The plots of figure 8 are transferred to such a triangle in figure 19. Whereas the modes of the Michigamme graywackes are 


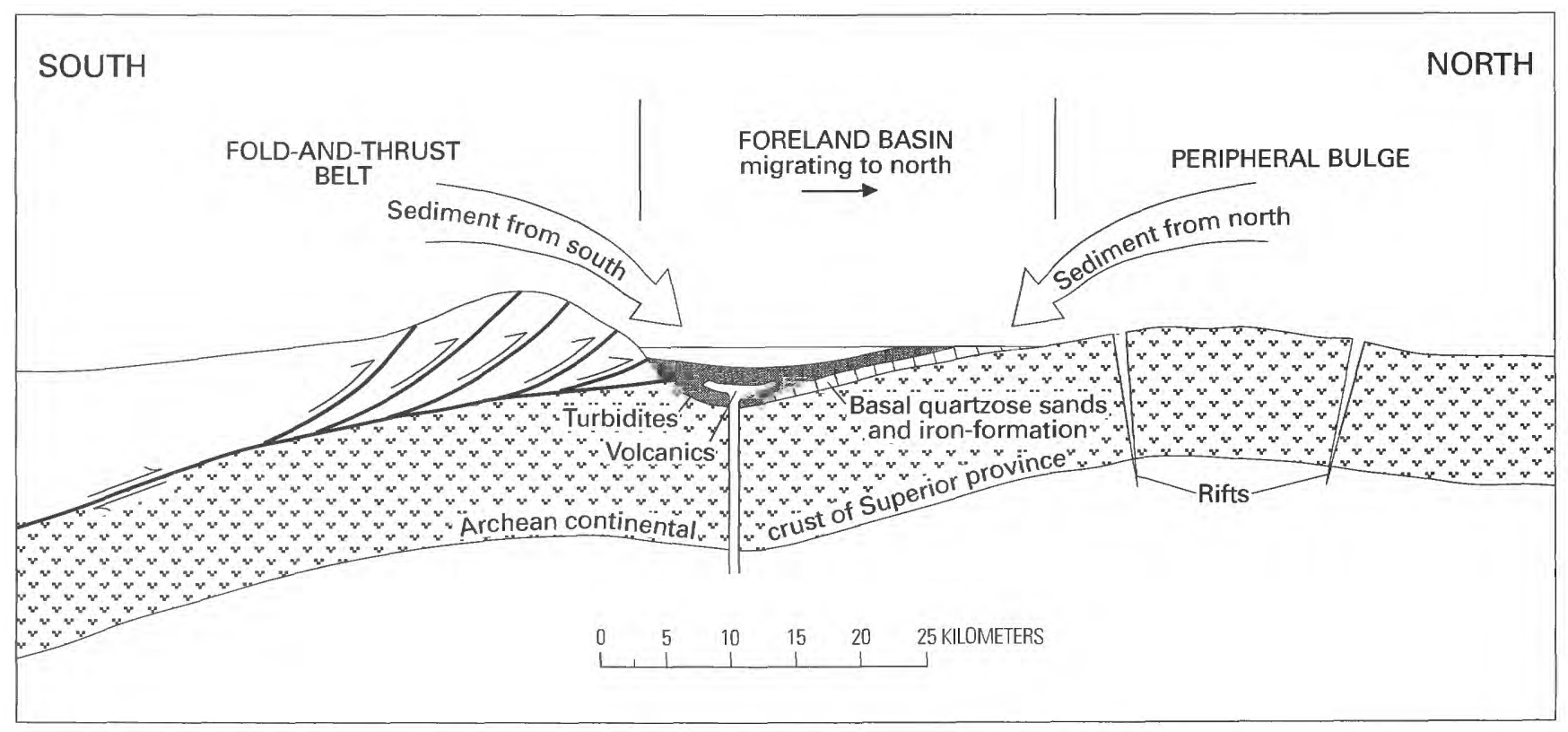

Figure 20. Schematic cross section depicting deposition of the Michigamme Formation in a foreland basin, with sediment derived from both north and south. The southern source area, the fold-and-thrust belt, comprises a complex assemblage including (1) accreted Early Proterozoic volcanic and plutonic rocks of the Wisconsin magmatic terranes, (2) accreted Archean miniplate terranes, (3) older Early Proterozoic passive-margin sedimentary rocks and volcanic rocks produced during initial rifting of the continental margin, both scraped off the southward-subducting Archean Superior craton, and (4) recycled initial foredeep deposits, possibly including basal shallow water sandstones deposited in the transgressing sea of the northward-migrating foreland basin. The peripheral bulge comprises a source-rock assemblage of Archean granitic rocks and Archean volcanic-sedimentary (greenstone) belts. The faults in the fold-and-thrust belt are related to the Niagara fault zone (suture). Compare with figure 21. Partly based on Hoffman (1987), Southwick and others (1988), and Southwick and Morey (1991). Scale is approximate.

probably not representative of original compositions, as discussed in the "Petrography" section of this report, they can be partially interpreted with regard to the average plots of the presumed correlative Rove, Thomson, Virginia, and Tyler Formations (also shown in figure 19), which are somewhat less metamorphosed and deformed than the Michigamme and therefore more representative of their primary sandstone compositions. The Rove Formation was derived entirely from the cratonal region to the north (Morey, 1967), as were the Thomson (Morey and Ojakangas, 1970) and Virginia Formations (Lucente and Morey, 1983); the northern exposed part of the Michigamme Formation probably also has a similar cratonal parentage.

In contrast, the southern Michigamme graywackes and the Tyler Formation probably had their source areas in the collisional zone to the south, a zone made up of Early Proterozoic volcanic-arc rocks, Archean basement rocks, and cover rocks of the craton margin. Yet, on the $\mathrm{Q} / \mathrm{F} / \mathrm{L}$ triangle (fig. 19), the southern graywackes plot with the northern graywackes. This coincidence is discussed following.

Several workers have interpreted the Animikie basin as an elongate easterly trending intracratonic basin, with sediment supplied from both the north and south sides. (See, for example, Sims and others, 1981; Ojakangas and Matsch, 1982, p. 43; Morey, 1983a, b.) Other workers proposed a subduction model on a continental margin to explain the asymmetry and the distribution of rock types, including the volcanic rocks to the south in Wisconsin. (Here, see Van Schmus, 1976; Cambray, 1978; Van Schmus and Bickford, 1981; Larue, 1983; LaBerge and others, 1984.)

Hoffman (1987) proposed a foreland basin model combined with a southward-dipping subduction zone to explain the interrelation of Early Proterozoic iron-formations, mafic volcanic rocks, and thick turbidite sequences, with the asymmetric basin being the product of loading by the northwardverging Penokean fold-and-thrust belt. A similar model, and also a back-arc basin model with northward subduction, were proposed to explain lithologic and structural relationships in east-central Minnesota detailed by Southwick and others (1988) and Southwick and Morey (1991).

I accept the foredeep model, with associated southward subduction and the collision of a volcanic arc (the Wisconsin magmatic terranes) with the craton to the north, as the model that can best explain the origin of the Michigamme Formation, as well as that of the correlative Copps and Tyler Formations (fig. 20). However, as noted previously, the clastics in the southern part of the Michigamme Formation appear to have had a different source than those in the northern part of the Michigamme.

Several lines of evidence support derivation of the clastic sediments in the southern outcrops of the Michigamme from a combination of a craton (Archean terrane) and a recycled 
orogen (Wisconsin magmatic terranes) to the south. (1) Paleocurrent plots of the Tyler, Copps, and the southern exposed part of the Michigamme suggest source areas to the south rather than to the north. (2) The Nd data of Barovich and others (1989) support an Early Proterozoic source for the Michigamme graywacke-slate sequence of the southern area. (3) $Q / F / L$ plots for the graywackes are suggestive of cratonal and recycled orogenic sources rather than direct magmatic arc sources for the detritus (fig. 19). (4) The CIA values (table 4) imply a moderate amount of weathering in the source areas and provide argument against a major direct volcanic source. (5) Regional paleogeography indicates that the Wisconsin magmatic terranes, south of the Niagara fault, together with Late Archean gneiss terranes, also to the south (fig. 2), were the likely source areas. These source rocks apparently comprised part of an imbricate sequence of northverging thrusts that formed a high-relief area. Interestingly, petrographic studies do not show the volume of clastic volcanic material that might be expected in sediments derived in part from the Wisconsin magmatic terranes. Possible explanations for this deficiency are (1) destruction of volcanic clasts by weathering in the source areas, (2) diagenetic and metamorphic alteration of the volcanic clasts, (3) destruction of the volcanic clasts by tectonic recycling and resedimentation, or (4) the failure of significant volumes of eroded volcanic detritus to reach the foreland basin. In the latter scenario, volcanic ash from the colliding arc could have been deposited in the basin, and this ash could have provided the Early Proterozoic source imprint ( $\mathrm{Nd}$ data) to the sedimentary rocks.

In the vicinity of the Michigan-Wisconsin border, lensoid exposures of quartzite exist within the Michigamme Formation (Sims and Schulz, 1992). The "Pine River member" (quartzite conglomerate of Nilssen, 1965), for example, can be either an older (Chocolay? Group) continental margin sedimentary unit or the basal quartzite (Goodrich Quartzite equivalent of an earlier stage of the northward-migrating foreland basin) incorporated into the fold-and-thrust belt. A roadcut on Wisconsin Highway 12, $20 \mathrm{~km}$ south of Covington, exposes possibly analogous sandstone lenses in muddy rock and thin sandstone beds with thin mud drapes or flasers; these are comparable to sedimentary structures in the lower member of the Michigamme, which are attributed herein to a tidal environment; these data suggest the possibility that the lower member of the Michigamme Formation exists in this area.

In contrast, the northern exposures of the Michigamme Formation are interpreted to have had a source to the north, for the following reasons: (1) The paleocurrent data, although sparse, support a northern source; (2) the Nd data of Barovich and others (1989) support an Archean source for the sediment of the northern Michigamme sequence; (3) $\mathrm{Q} / \mathrm{F} / \mathrm{L}$ plots for the graywacke, in spite of likely postdepositional changes, indicate a cratonic or recycled orogen source; (4) CIA values (table 5) indicate a moderately weathered source area; and (5) regional paleogeography supports the Archean granite-greenstone terrane of northern Minnesota and Ontario and the Archean northern complex of Michigan as plausible, likely source areas. The Dead River, Clark Creek, East Baraga, and Gwinn basins (fig. 3) are small down-folded and down-faulted erosional remnants (Sims, 1991, fig. 1) of the widespread and once continuous Michigamme sequence.

Paleocurrent indicators in the Rove Formation on the north side of Lake Superior, in Minnesota and Ontario, show a strong mode toward the south (Morey, 1967; fig. 21), similar to that of the northern segment of the Michigamme Formation. Any paleogeographic reconstruction, however, must allow for the spreading that occurred during the formation of the 1,100 Ma Midcontinent rift system, which is situated in the Lake Superior basin between Michigan and Minnesota-Ontario (fig. 2). The amount of spread between the two Archean-Early Proterozoic terranes has been estimated to be 60-100 km (Klasner and others, 1982; Chandler, 1983). If the regional paleogeography is restored to its preMidcontinent rift position by moving the block situated southeast of the Midcontinent rift system a distance of 100 $\mathrm{km}$ in a northwesterly direction (perpendicular to the trend of the rift), the distance between the northern Michigamme exposures and the southernmost Rove exposures is reduced to an estimated $65-100 \mathrm{~km}$. It seems probable that the finegrained northern Michigamme is "distal Rove Formation," deposited on the distal portion of a southward-thinning submarine fan or on the basin plain, for both formations have paleocurrent patterns towards the south and an Archean provenance (fig. 21). In this interpretation, both the Rove and the northern Michigamme were deposited on the north side of the asymmetric foreland basin (on the continental foreland or the peripheral bulge), whereas the southern Michigamme was deposited nearer the axis of the asymmetric foreland basin. Note that this restoration (fig. 21) also results in the alignment of the fold-and-thrust belts of Minnesota and Wisconsin-Michigan.

Whereas the Michigamme graywacke and slate were probably derived from relatively distant source areas, the basal quartzose sandstone underlying the Michigamme Formation (the Goodrich Quartzite) was evidently derived locally. Its composition includes potassium feldspar and plutonic rock fragments (table 2). These components, when coupled with the paleocurrent data (figs. 16, 17) that show paleocurrents radiating southwestward, westward, and northward from the Archean northern complex, indicate local derivation from these Archean granitoid rocks. The sands composed of quartz, feldspar, and plutonic rock fragments were apparently reworked in a shallow-water tidal environment, thereby becoming mineralogically and texturally mature. These shallow-water deposits can be interpreted to have been deposited along the northern shoreline (on the continental foreland or the peripheral bulge) of the northward-migrating foreland basin. 


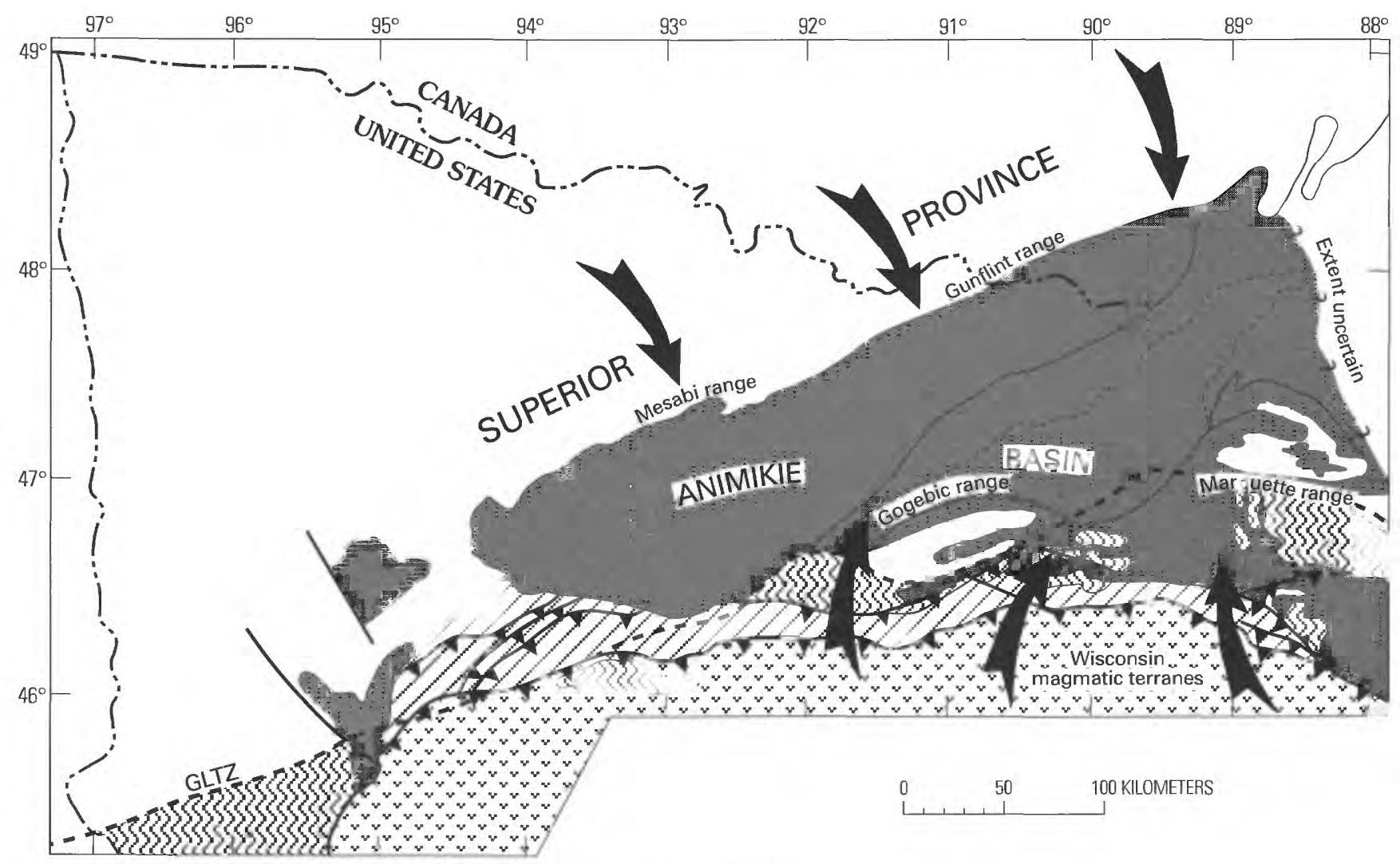

EXPLANATION

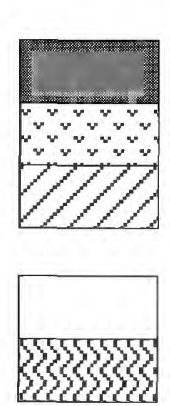

Early Proterozoic

Turbidites overlying shelf deposits

Plutonic and volcanic rocks

Complex continental-margin sequences

Archean

Rocks of greenstone-granite terrane (Superior province)

Rocks of gneiss terrane

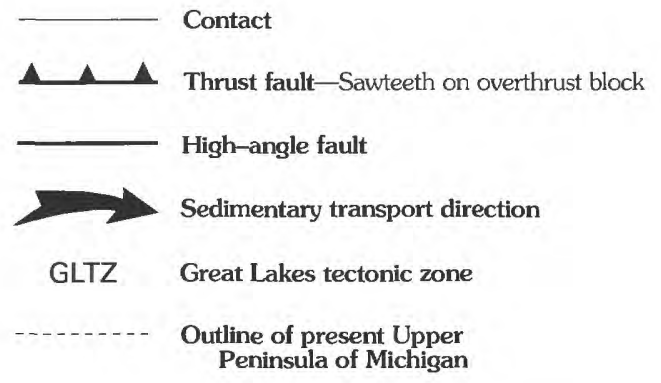

Figure 21. Schematic hypothesized paleogeography at time of sedimentation of the Michigamme Formation. The rocks of the Midcontinent rift system have been removed, and Michigan is positioned $100 \mathrm{~km}$ closer to Minnesota-Ontario. Arrows denote generalized transportation directions of sediment from major source areas. Compare with figures 2 and 20. Map modified from Sims (1991) and Southwick and Morey (1991).

The island landmass in the Early Proterozoic sea, now constituting the northern complex (fig. 17), probably was eventually totally submerged and covered with sediments. On the southern part of this landmass, the stratigraphic sequence is complete, as in drill holes DL-4 and DL-5 in the Dead River and Clark Creek basins (figs. 3, 7). To the north in the East Baraga basin, the Goodrich Quartzite and the lower slate member of the Michigamme Formation were not deposited, as shown by drill holes DL 7 and DDH-116 (locations, fig. 3; text, p. 8). Evidently this part of the landmass was topographically higher than the area to the south, and was onlapped only by the higher stratigraphic units (the Bijiki Iron-formation Member and the upper slate member). By late Michigamme time, the entire landmass was submerged and covered by the upper slate member. Subsequent uplift and erosion of the cover rocks exposed most of this landmass of Archean rocks, except where the cover rocks were downfaulted and preserved in three small structural basins-the Dead River, Clark Creek, and East Baraga basins. 


\section{STRATIGRAPHIC IMPLICATIONS}

This study raises numerous stratigraphic questions that challenge the long-accepted correlations shown in figure 1. Some revisions of regional correlations seem to be required, as discussed following.

The stratigraphic sequence in outcrop and drill core in the northern part of the study area comprises the Goodrich Quartzite and the overlying Michigamme Formation, consisting of the lower slate member, the Bijiki Iron-formation Member, and the upper slate member. A similar stratigraphic sequence occurs on the Gogebic range, which is $120-160$ $\mathrm{km}$ to the west-southwest and is on depositional and tectonic strike with the western Marquette district (fig. 3). On the Gogebic range, the relevant stratigraphic units, from oldest to youngest, are the Palms Formation, the Ironwood Ironformation, and the Tyler and Copps Formations. Not only are the lithologies generally similar between the two ranges, but the interpreted depositional environments are similar. These units were likely deposited contemporaneously in the northward-transgressing Early Proterozoic (Animikie) sea situated in the developing foreland basin. The proposed correlations between the Gogebic and the western Marquette ranges are, therefore, as follows:

\begin{tabular}{cc}
\hline \multicolumn{1}{c}{ Gogebic range } & Western Marquette range \\
\hline Tyler and Copps Formations & $\begin{array}{c}\text { Upper slate member, } \\
\text { Michigamme Formation. }\end{array}$ \\
\hline Ironwood Iron-formation & $\begin{array}{r}\text { Bijiki Iron-formation Member, } \\
\text { Michigamme Formation. } \\
\text { Palms Formation }\end{array}$ \\
& $\begin{array}{c}\text { Lower slate member, } \\
\text { Michigamme Formation. } \\
\text { Goodrich Quartzite. }\end{array}$ \\
\hline
\end{tabular}

The stratigraphic sequences to the north on the Gunflint and Mesabi ranges (fig. 2) are also similar to those on the Gogebic range and the western Marquette range, in both lithologies and environments of deposition. On the Mesabi, the basal unit (the Pokegama Quartzite) fits a tidal model, the two "cherty" members of the Biwabik Iron-formation have shallow-water attributes, and the two "slaty" members have deeper water attributes (White, 1954; Ojakangas, 1983; Morey, 1983a). The overlying Virginia Formation was deposited below wave base by turbidity currents and suspension settling on the outer or middle parts of a submarine fan complex (Lucente and Morey, 1983). The lowermost unit on the Gunflint range, the Kakabeka Quartzite, which lies unconformably upon Archean basement, is at most only a few meters thick and hence its environment of deposition is difficult to interpret. However, the overlying Gunflint Iron-formation has shallow-water tidal attributes (Goodwin, 1956; Shegelski, 1980), and the uppermost unit, the Rove Formation, has characteristics of turbidity current deposition on a prograding submarine fan (Morey, 1969). Therefore, the depositional histories on the Mesabi and Gunflint ranges, which are on depositional strike with each other and very likely were continuous before intrusion of the $1.1 \mathrm{Ga}$ Duluth Complex, are very similar; and lithostratigraphic correlations between these two ranges are unequivocal.

Although correlations can be made, on the one hand, between the western Marquette range and the Gogebic range, and on the other hand, between the Mesabi and Gunflint ranges, can correlations be made among all four of these ranges? The lithologies, environments of deposition, and stratigraphic sequences are indeed similar, indicating a strong case for correlation. However, diachronous relationships between the western Marquette and Gogebic ranges to the south and the Mesabi and Gunflint ranges to the north are required. If the model of a northward-migrating foreland basin is utilized (figs. 20,21), with the basal terrigenous clastic units and the iron-formations deposited on the peripheral bulge and the turbidite sequences deposited both on the bulge and in the deeper parts of the foreland basin, the Palms Formation-Ironwood Iron-formation and Goodrich Quartzite-lower member of the Michigamme Formation-Bijiki Iron-formation Member were deposited prior to deposition of the more northerly Pokegama Quartzite-Biwabik Ironformation and the Kakabeka Quartzite-Gunflint Formation. If it is instead assumed that the basal terrigenous clastic units and the iron-formations were deposited on a stable shelf prior to the development of the foreland basin with its turbidite fill, northward-migrating depositional environments were also probable, with the southern units deposited prior to deposition of the northern units. In both models, it can be assumed that the terrigenous clastic units and the overlying iron-formations form essentially continuous sheetlike deposits across the basin, between Wisconsin-Michigan and Minnesota-Ontario.

However, as discussed previously in this report, the upper slaty member of the northern part of the Michigamme Formation and the Rove Formation of Minnesota-Ontario are the same age, and perhaps integral parts of the same large submarine fan. A further correlation consequence of this model (stated just previously) is that the Virginia Formation of the Mesabi range and the Thomson Formation just west of Duluth, both on tectonic and depositional strike with the Rove Formation (see figs. 2, 21), are approximately equivalent in age to the upper slaty member of the Michigamme Formation. No direct means exists to determine whether the graywacke-slate units having general northward-directed paleocurrent patterns (the Tyler and Copps Formations and the southern Michigamme Formation) are younger or older than the Virginia, Thomson, and Rove Formations and the upper slaty member of the Michigamme Formation; it can be assumed, however, that they are all approximately the same age, and correlative. However, there exist two main qualifying points, as follows.

1. In a foreland basin such as that which probably existed for several million years and which was receiving 
sediment from both north and south, units will inevitably be different in age.

2. In the foreland basin model, the fold-and-thrust belt and the asymmetric foreland basin to the north developed as a result of the collision of the Wisconsin magmatic terranes with the craton. The collision caused the Penokean orogeny, which is dated at about $1,850 \mathrm{Ma}$. Thus, the southerly derived graywacke-slate units were deposited about 1,850 Ma.

Of prime concern, therefore, are the contacts of the southerly derived graywacke-slate units with the underlying ironformations. Are the relationships conformable or nonconformable? If conformable, the ages of the Ironwood Iron-formation and the Bijiki Iron-formation Member of the Michigamme Formation would not be much older than 1,850 Ma. If unconformable, the iron-formations and the terrigenous clastic units that underlie them could be considerably older. I have seen no evidence in outcrop or in drill core for an unconformable relationship between the Bijiki Iron-formation Member and the overlying upper slate member of the Michigamme Formation. The Tyler Formation-Ironwood Iron-formation relationship has been described by Schmidt (1980, p. 68-70), who reviewed the various viewpoints of geologists regarding the contact. Schmidt regarded the "basal conglomerate" of the Tyler Formation as an intraformational unit of no great stratigraphic significance, and emphasized that both the presence of iron-formation a few hundred meters above the base of the Tyler and the ironrich nature of the lower part of the formation indicated a gradational contact.

However, the Copps Formation just to the east of the Tyler on the eastern Gogebic range, and surely correlative with it, has a basal conglomerate that contains iron-formation clasts. Thus, the contact between the Copps and the Ironwood Iron-formation is probably unconformable (Gene LaBerge, oral commun., 1992). This appears to be a local rather than a regional unconformity.

The Virginia Formation-Biwabik Iron-formation contact on the Mesabi range is gradational over several tens of meters (Lucente and Morey, 1983), and the Rove Formation-Gunflint Iron-formation boundary also is gradational (Morey, 1969).

Thus, the precise ages and therefore the correlation of several Early Proterozoic units are uncertain. Crosscutting dikes of Early Proterozoic age are lacking. Many K-Ar and $\mathrm{Rb}-\mathrm{Sr}$ ages probably reflect metamorphism. Faure and Kovach (1969) reported a whole-rock $\mathrm{Rb}$-Sr isochron age of $1.64 \pm 0.2 \mathrm{Ga}$ for the deposition or diagenesis of the Gunflint Iron-formation in Ontario, and Stille and Clauer (1986) determined a Sm-Nd isochron age of $2.08 \pm 0.25 \mathrm{Ga}$ for deposition of the same unit. A Sm-Nd whole rock isochron for the lower half of the Biwabik Iron-formation indicated an age of 2,110 $\pm 0.52 \mathrm{Ma}$ (Gerlach and others, 1988).

Essential to the resolution of the correlations discussed herein will be the acquisition of better ages from within the sequences. Zircons for precise $\mathrm{U}-\mathrm{Pb}$ age dating should be present in the metamorphosed ash beds of the Virginia Formation and the Biwabik and Gunflint Iron-formations. Volcanic rocks within the Thomson Formation could yield zircons. Perhaps a detailed search of the Michigamme in drill cores would yield zircon-bearing ash beds. If the felsic parts of the Emperor Volcanic Complex at the east end of the Gogebic range are shown to be unequivocally intercalated with the Ironwood Iron-formation, U-Pb dates for zircons of that unit would be invaluable.

Until reliable age data on units within the Early Proterozoic sequences are available, correlations will necessarily remain subjective, and interpretive errors will be perpetuated.

\section{REFERENCES CITED}

Aldrich, H.R., 1929, The geology of the Gogebic iron range of Wisconsin: Wisconsin Geological and Natural History Survey Bulletin 17, $279 \mathrm{p}$.

Alwin, B.W., 1976, Sedimentation of the Middle Precambrian Tyler Formation of north-central Wisconsin and northwestern Michigan: Duluth, Minn., University of Minnesota M.S. thesis, $200 \mathrm{p}$.

Attoh, K., and Klasner, J.S., 1989, Tectonic implications of metamorphism and gravity field in the Penokean orogen of northern Michigan: Tectonics, v. 8, p. 911-933.

Bailes, A.H., 1980, Origin of early Proterozoic volcaniclastic turbidites, south margin of the Kisseynew sedimentary gneiss belt, File Lake, Manitoba: Precambrian Research, v. 12, p. 197-225.

Barovich, K.M., Patchett, P.J., Peterman, Z.E., and Sims, P.K., $1989, \mathrm{Nd}$ isotopes and the origin of 1.9-1.7 Ga Penokean continental crust of the Lake Superior region: Geological Society of America Bulletin, v. 101, p. 333-338.

Bayley, R.W., Dutton, C.E., and Lamey, C.A., 1966, Geology of the Menominee iron-bearing district, Michigan and Wisconsin: U.S. Geological Survey Professional Paper 513, $96 \mathrm{p}$.

Burns, G.K., 1975, Middle Precambrian black slate of the Baraga basin, Baraga County, Michigan: Bowling Green, Ohio, Bowling Green State University M.S. thesis, 129 p.

Cambray, F.W., 1978, Plate tectonics as a model for the development of deposition and deformation of the early Proterozoic (Precambrian X) of northern Michigan: Geological Society of America Abstracts with Programs, v. 10 , p. 376.

1987, An alternative stratigraphic correlation within the Marquette Range Supergroup, N. Michigan: Geological Society of America Abstracts with Programs, v. 19, p. 192.

Cannon, W.F., 1973, The Penokean orogeny in northern Michigan, in Young, G.M., ed., Huronian stratigraphy and sedimentation: Geological Association of Canada Special Paper 12, p. 251-271.

1974, Bedrock geologic map of the Greenwood quadrangle, Marquette County, Michigan: U.S. Geological Survey Geologic Quadrangle Map GQ-1168, scale 1:24,000.

1975, Bedrock geologic map of the Republic quadrangle, Marquette County, Michigan: U.S. Geological Survey 
Miscellaneous Investigations Series Map 1-862, scale $1: 24,000$.

1986, Bedrock geologic map of the Iron River $1^{\circ} \times 2^{\circ}$ quadrangle, Michigan and Wisconsin: U.S. Geological Survey Miscellaneous Investigations Series Map I-1360-B, scale 1:250,000.

Cannon, W.F., and Gair, J.E., 1970, A revision of stratigraphic nomenclature of Middle Precambrian rocks in northern Michigan: Geological Society of America Bulletin, v. 81, p. 2843-2846.

Cannon, W.F., and Klasner, J.S., 1975, Stratigraphic relationships within the Baraga Group of Precambrian age, central Upper Peninsula, Michigan: U.S. Geological Survey Journal of Research, v. 3, p. 47-51.

1976a, Geologic map and geophysical interpretation of the Witch Lake quadrangle, Marquette, Iron, and Baraga Counties, Michigan: U.S. Geological Survey Miscellaneous Investigations Series Map I-987, scale 1:24,000.

$1976 \mathrm{~b}$, Phosphorite and other apatite-bearing sedimentary rocks in the Precambrian of northern Michigan: U.S. Geological Survey Circular 746, 6 p.

1977 , Bedrock geologic map of the southern part of the Diorite and Champion 71/2-minute quadrangles, Marquette County, Michigan: U.S. Geological Survey Miscellaneous Investigations Series Map I-1058, scale 1:24,000.

1980, Bedrock geologic map of the Kenton-Perch Lake area, northern Michigan: U.S. Geological Survey Miscellaneous Investigations Series Map I-1290, scale $1: 62,500$.

Chandler, V.W., 1983, Correlation of magnetic anomalies in eastcentral Minnesota and northwestern WisconsinConstraints on magnitude and direction of Keweenawan rifting: Geology, v. 11, p. 174-176.

Clark, L.D., Cannon, W.F., and Klasner, J.S., 1975, Bedrock geologic map of the Negaunee SW quadrangle, Marquette County, Michigan: U.S. Geological Survey Geologic Quadrangle Map GQ-1226, scale 1:24,000.

Cleveland-Cliffs Iron Co., Ishpeming, Michigan, 1975, Marquette mineral district map, Marquette and Baraga Counties, Michigan

Dickinson, W.R., Beard, L.S., Brakenridge, G.R., Erjavec, J.L., Ferguson, R.C., Inman, K.F., Knepp, R.A., Lindberg, F.A., and Ryberg, P.T., 1983, Provenance of North American Phanerozoic sandstones in relation to tectonic setting: Geologic Society of America Bulletin, v. 94, p. 222-235.

Faure, G., and Kovach, J., 1969, The Age of the Gunflint Iron Formation of the Animikie Series in Ontario, Canada: Geological Society of America Bulletin, v. 80 , p. 1725-1736.

Foose, M.P., 1981, Geologic map of the Ned Lake quadrangle, Iron and Baraga Counties, Michigan: U.S. Geological Survey Miscellaneous Investigations Series Map I-1284, scale $1: 24,000$.

Gair, J.E., and Thaden, R.E., 1968, Geology of the Marquette and Sands quadrangles, Marquette County, Michigan: U.S. Geological Survey Professional Paper 397, 77 p.

Gerlach, D.C., Shirey, S.B., and Carlson, R.W., 1988, Nd isotopes in Proterozoic Iron Formations-Evidence for mixed-age provenance and depositional variability [abs.]: American Geophysical Union, San Francisco Fall Meeting Abstract Volume.

Goodwin, A.M., 1956, Facies relations in the Gunflint ironformation: Economic Geology, v. 51, p. 565-595.
Gregg, W.J., 1993, Structural geology of parautochthonous and allochthonous terranes of the Penokean orogeny in Upper Michigan-Comparisons with northern Appalachian tectonics: U.S. Geological Survey Bulletin 1904-Q, 28 p.

Hoffman, P.F., 1987, Early Proterozoic foredeeps, foredeep magmatism, and Superior-type iron-formations of the Canadian Shield, in Kroner, A., ed., Proterozoic lithospheric evolution, Geodynamic Series: American Geophysical Union, v. 17, p. 85-98.

Holst, T.B., 1991, The Penokean orogeny in Minnesota and Upper Michigan-A comparison of structural geology: U.S. Geological Survey Bulletin 1904-D, 10 p.

James, H.L., 1955, Zones of regional metamorphism in the Precambrian of northern Michigan: Geological Society of America Bulletin, v. 66, p. 1455-1488.

1958, Stratigraphy of pre-Keweenawan rocks in parts of northern Michigan: U.S. Geological Survey Professional Paper 314-C, p. 27-44.

James, H.L., Clark, L.D., Lamey, C.A., and Pettijohn, F.J., in collaboration with Freedman, J., Trow, J., and Wier, K.L., 1961, Geology of central Dickinson County, Michigan: U.S. Geological Survey Professional Paper 310, 176 p.

Klasner, J.S., 1978, Penokean deformation and associated metamorphism in the western Marquette range, northem Michigan: Geological Society of America Bulletin, v. 89, p. 711-722.

Klasner, J.S., and Cannon, W.F., 1978, Bedrock geologic map of the southern part of the Michigamme and Three Lakes quadrangles, Marquette and Baraga Counties, Michigan: U.S. Geological Survey Miscellaneous Investigations Series Map I-1078, scale 1:24,000.

1989, Segment 2-Geology of the Marquette Range Supergroup and the Penokean foldbelt in northern Michigan, in Morey, G.B., ed.. Early Proterozoic rocks of the Great Lakes region: 28th International Geologic Congress, Field Trip Guidebook T145, p. 19-31.

Klasner, J.S., Cannon, W.F., and Van Schmus, W.R., 1982, The pre-Keweenawan tectonic history of southern Canadian Shield and its influence on formation of the Midcontinent Rift, in Wold, R.J., and Hinze, W.J., eds., Geology and tectonics of the Lake Superior Basin: Geological Society of America Memoir 156, p. 27-46.

Klasner, J.S., Ojakangas, R.W., Schulz, K.J., and LaBerge, G.L., 1991, Nature and style of Early Proterozoic deformation in the foreland of the Penokean orogen, Michigan: U.S. Geological Survey Bulletin 1904-K, 22 p.

Klasner, J.S., and Sims, P.K., 1993, Thick-skinned, south-verging backthrusting in the Felch and Calumet troughs area of the Penokean orogen, northern Michigan: U.S. Geological Survey Bulletin 1904-L, 28 p.

Klasner, J.S., Sims, P.K., Gregg, W.J., and Gallup, Christina, 1988, A structural traverse across a part of the Penokean orogen, illustrating Early Proterozoic overthrusting in northern Michigan, in Schulz. K.J., ed., Field trip guidebooks, Volume 2: 34th Annual Institute on Lake Superior Geology, Marquette, Michigan, p. C1-C36.

Klein, G. de Vries, 1975, Sandstone depositional models for exploration for fossil fuels: Champaign, Ill., Continuing Education Publishing Company, P.O. Box 2590, Station A, $109 \mathrm{p}$.

La Berge, G.L., Schulz, K.J., and Myers, P.E., 1984, The plate tectonic history of north-central Wisconsin [abs.]: 30th 
Annual Institute on Lake Superior Geology, Wausau, Wisconsin, p. 25-27.

Larue, D.K., 1983, Early Proterozoic tectonics of the Lake Superior region-Tectonostratigraphic terranes near the purported collision zone, in Medaris, L.G., Jr., ed., Early Proterozoic geology of the Lake Superior region: Geological Society of America Memoir 160, p. 33-47.

Leith, C.K., Lund, R.J., and Leith, Andrew, 1935, Pre-cambrian rocks of the Lake Superior region: U.S. Geological Survey Professional Paper 184, 34 p.

Lucente, M.E., and Morey, G.B., 1983, Stratigraphy and sedimentology of the Lower Proterozoic Virginia Formation, northern Minnesota: Minnesota Geological Survey Report of Investigations $28,28 \mathrm{p}$.

Mancuso, J.J., Lougheed, M.S., and Shaw, R., 1975, Carbonateapatite in Precambrian cherty iron-formation, Baraga County, Michigan: Economic Geology, v. 70, p. 583-586.

Morey, G.B., 1967, Stratigraphy and sedimentology of the Middle Precambrian Rove Formation in northeastern Minnesota: Journal of Sedimentary Petrology, v. 37, p. 1154-1162.

1969, The geology of the Middle Precambrian Rove Formation in northeastern Minnesota: Minnesota Geological Survey Special Publication SP-7, 62 p.

1978, Metamorphism in the Lake Superior region, U.S.A., and its relation to crustal evolution, in Fraser, J.A., and Heywood, W.W., eds., Metamorphism in the Canadian Shield: Geological Survey of Canada Paper 78-10, p. 283-314.

1983a, Animikie basin, Lake Superior region, U.S.A., in Trendall, A.F., and Morris, R.C., eds., Ironformation-Facts and problems: Amsterdam, Elsevier, p. 13-67.

1983b, Lower Proterozoic stratified rocks and the Penokean orogeny in east-central Minnesota, in Medaris, L.G., Jr., ed., Early Proterozoic geology of the Lake Superior region: Geological Society of America Memoir 160, p. 97-112.

Morey, G.B., and Ojakangas, R.W., 1970, Sedimentology of the Middle Precambrian Thomson Formation, east-central Minnesota: Minnesota Geological Survey Report of Investigations $13,32 \mathrm{p}$.

Morey, G.B., and Van Schmus, W.R., 1988, Correlation of Precambrian rocks of the Lake Superior region, United States: U.S. Geological Survey Professional Paper 1241-F, $31 \mathrm{p}$.

Nanz, R.H., Jr., 1953, Chemical composition of Pre-Cambrian slates with notes on the geochemical evolution of lutites: Journal of Geology, v. 61, p. 51-64.

Nesbitt, H.W., and Young, G.M., 1982, Early Proterozoic climates and plate motions inferred from major element chemistry of lutites: Nature, v. 299, p. 715-717.

Nilsen, T.E., 1965, Sedimentology of the middle Precambrian Animikian quartzites, Florence County, Wisconsin: Journal of Sedimentary Petrology, v. 35, p. 805-817.

Ojakangas, R.W., 1983, Tidal deposits in the early Proterozoic basin of the Lake Superior region-The Palms and the Pokegama Formations; Evidence for subtidal-shelf deposition of Superior-type banded iron-formation, in Medaris, L.G., Jr., ed., Early Proterozoic geology of the Lake Superior region: Geological Society of America Memoir 160 , p. $49-66$.

1986, An early Proterozoic metagraywacke-slate turbidite sequence-The Tampere Schist Belt, southwestern Finland: Bulletin Geological Society of Finland, v. 58, p. 241-261.
Ojakangas, R.W., and Matsch, C.L., 1982, Minnesota's geology: Minneapolis, Minn., University of Minnesota Press, 255 p.

Pettijohn, F.J., Potter, P.E., and Siever, R., 1987, Sand and sandstone, 2nd edition: New York, Springer-Verlag, 553 p.

Puffett, W.P., 1974, Geology of the Negaunee quadrangle, Marquette County, Michigan: U.S. Geological Survey Professional Paper 788, 53 p., scale 1:24,000.

Schmidt, R.G., 1980, The Marquette Range Supergroup in the Gogebic iron district, Michigan and Wisconsin: U.S. Geological Survey Bulletin 1460, 96 p.

Schulz, K.J., 1983, Geochemistry of the volcanic rocks of northeastern Wisconsin [abs.]: 29th Annual Institute on Lake Superior Geology, Houghton, Michigan, Michigan Technological University, Proceedings and Abstracts, p. 39. 1984, Early Proterozoic Penokean igneous rocks of the Lake Superior region-Geochemistry and tectonic implications [abs.]: 30th Annual Institute on Lake Superior Geology, Wausau, Wisconsin, Proceedings and Abstracts, p. 65-66.

Shegelski, R.J., 1980, Stratigraphy of the Gunflint Formation, Current River Area, Thunder Bay [abs.]: 26th Institute on Lake Superior Geology, Eau Claire, Wisconsin, University of Wisconsin-Eau Claire, Proceedings and Abstracts, p. 28.

Sims, P.K., 1990, Geologic map of Precambrian rocks of parts of Iron Mountain and Escanaba $1^{\circ} \times 2^{\circ}$ quadrangles, northeastern Wisconsin and adjacent Michigan: U.S. Geological Survey Miscellaneous Investigations Series Map I-2056, scale 1:250,000.

1991, Great Lakes tectonic zone in Marquette area, Michigan-Implications for Archean tectonics in northcentral United States: U.S. Geological Survey Bulletin 1904-E, $17 \mathrm{p}$.

Sims, P.K., compiler, 1992, Geologic map of Precambrian rocks, southern Lake Superior region, Wisconsin and northern Michigan: U.S. Geological Survey Miscellaneous Investigations Series Map I-2185, scale 1:500,000.

Sims, P.K., Card, K.D., and Lumbers, S.B., 1981, Evolution of early Proterozoic basins of the Great Lakes region, in Campbell, F.H.A., ed., Proterozoic basins of Canada: Geological Survey of Canada Paper 81-10, p. 379-397.

Sims, P.K., and Day, W.C., 1993, The Great Lakes tectonic zone-Revisited: U.S. Geological Survey Bulletin 1904-S, $11 \mathrm{p}$.

Sims, P.K., and Peterman, Z.E., 1983, Evolution of Penokean foldbelt, Lake Superior region, and its tectonic environments, in Medaris, L.G., Jr., ed., Early Proterozoic geology of the Lake Superior region: Geological Society of America Memoir 160, p. 3-14.

Sims, P.K., Peterman, Z.E., Prinz, W.C., and Benedict, F.C., 1984, Geology, geochemistry and age of Archean and Early Proterozoic rocks in the Marenisco-Watersmeet area, northern Michigan: U.S. Geological Survey Professional Paper 1292-A, 41 p.

Sims, P.K., and Schulz, K.J., 1992, Geologic map of Precambrian rocks of parts of Iron Mountain and Escanaba 30' $\times 60^{\prime}$ quadrangles, northeastern Wisconsin and adjacent Michigan: U.S. Geological Survey Miscellaneous Investigations Series Map I-2356, scale 1:100,000.

Sims, P.K., Van Schmus, W.R., Schulz, K.J., and Peterman, Z.E., 1989, Tectono-stratigraphic evolution of the Early Proterozoic Wisconsin magmatic terranes of the Penokean orogen: Canadian Journal of Earth Science, v. 26, p. 2145-2158. 
Southwick, D.L., and Morey, G.B., 1991, Tectonic imbrication and foredeep development in the Penokean orogen, east-central Minnesota-An interpretation based on regional geophysics and results of test-drilling: U.S. Geological Survey Bulletin 1904-C, 17 p.

Southwick, D.L., Morey, G.B., and McSwiggen, P.L., 1988, Geologic map (scale 1:250,000) of the Penokean orogen, central and eastern Minnesota, and accompanying text: Minnesota Geological Survey Report of Investigations 37, $25 \mathrm{p}$.

Stille, P., and Clauer, N., 1986, Sm-Nd isochron-age and provenance of the argillites of the Gunflint Iron Formation in Ontario, Canada: Geochimica et Cosmochimica Acta, v. 50, p. 1141-1146.

Trow, James, 1979, Final report-Diamond drilling for geologic information in the Middle Precambrian basins in the western portion of northern Michigan: Michigan Department of Natural Resources, prepared for the U.S. Department of Energy, Report GJBX-162(79), 123 p.

Tyler, S.A., and Twenhofel, W.H., 1952, Sedimentation and stratigraphy of the Huronian of upper Michigan: American Journal of Science, v. 250, Part I, p. 1-27, and Part II, p. 118-151.

Van Hise, C.R., and Bayley, W.S., 1897, The Marquette ironbearing district of Michigan, including a chapter on The
Republic Trough by H.L. Smyth: U.S. Geological Survey Monograph 28, 608 p.

Van Schmus, W.R., 1976, Early and Middle Proterozoic history of the Great Lakes area, North America: Philosophical Transactions of the Royal Society of London, Series A, v. 280, p. 605-628.

Van Schmus, W.R., and Bickford, M.E., 1981, Proterozoic chronology and evolution of the Midcontinent region, North America, in Kroner, A., ed., Precambrian plate tectonics, Developments in Precambrian geology: New York, Elsevier, p. 261-296.

Walker, R.G., 1967, Turbidite sedimentary structures and their relationship to proximal and distal depositional environments: Journal of Sedimentary Petrology, v. 37, p. 25-43.

1984, Turbidites and associated coarse clastic deposits, in Walker, R.G., ed., Facies models: Geoscience Canada Reprint Series 1, p. 171-188.

Walker, R.G., and Mutti, Emiliano, 1973, Turbidite facies and facies associations, in SEPM Pacific Section Short Course, Turbidites and deep water sedimentation: Anaheim, Calif., p. 119-157.

White, D.A., 1954, The stratigraphy and structure of the Mesabi Range, Minnesota: Minnesota Geological Survey Bulletin $38,92 \mathrm{p}$.

Manuscript approved for publication July 12, 1993

Published in the Central Region, Denver, Colorado

Photocomposition by Shelly A. Fields

Graphics by Gayle M. Dumonceaux 


\section{SELECTED SERIES OF U.S. GEOLOGICAL SURVEY PUBLICATIONS}

\section{Periodicals}

Earthquakes \& Volcanoes (issued bimonthly).

Preliminary Determination of Epicenters (issued monthly).

\section{Technical Books and Reports}

Professional Papers are mainly comprehensive scientific reports of wide and lasting interest and importance to professional scientists and engineers. Included are reports on the results of resource studies and of topographic, hydrologic, and geologic investigations. They also include collections of related papers addressing different aspects of a single scientific topic.

Bulletins contain significant data and interpretations that are of lasting scientific interest but are generally more limited in scope or geographic coverage than Professional Papers. They include the results of resource studies and of geologic and topographic investigations; as well as collections of short papers related to a specific topic.

Water-Supply Papers are comprehensive reports that present significant interpretive results of hydrologic investigations of wide interest to professional geologists, hydrologists, and engineers. The series covers investigations in all phases of hydrology, including hydrology, availability of water, quality of water, and use of water.

Circulars present administrative information or important scientific information of wide popular interest in a format designed for distribution at no cost to the public. Information is usually of short-term interest.

Water-Resources Investigations Reports are papers of an interpretive nature made available to the public outside the formal USGS publications series. Copies are reproduced on request unlike formal USGS publications, and they are also available for public inspection at depositories indicated in USGS catalogs.

Open-File Reports include unpublished manuscript reports, maps, and other material that are made available for public consultation at depositories. They are a nonpermanent form of publication that may be cited in other publications as sources of information.

\section{Maps}

Geologic Quadrangle Maps are multicolor geologic maps on topographic bases in $71 / 2$ - or 15 -minute quadrangle formats (scales mainly $1: 24,000$ or $1: 62,500$ ) showing bedrock, surficial, or engineering geology. Maps generally include brief texts; some maps include structure and columnar sections only.

Geophysical Investigations Maps are on topographic or planimetric bases at various scales, they show results of surveys using geophysical techniques, such as gravity, magnetic, seismic, or radioactivity, which reflect subsurface structures that are of economic or geologic significance. Many maps include correlations with the geology.

Miscellaneous Investigations Series Maps are on planimetric or topographic bases of regular and irregular areas at various scales; they present a wide variety of format and subject matter. The series also includes 7 1/2-minute quadrangle photogeologic maps on planimetric bases which show geology as interpreted from aerial photographs. The series also includes maps of Mars and the Moon.
Coal Investigations Maps are geologic maps on topographic or planimetric bases at various scales showing bedrock or surficial geology, stratigraphy, and structural relations in certain coal-resource areas.

Oil and Gas Investigations Charts show stratigraphic information for certain oil and gas fields and other areas having petroleum potential.

Miscellaneous Field Studies Maps are multicolor or black-andwhite maps on topographic or planimetric bases on quadrangle or irregular areas at various scales. Pre-1971 maps show bedrock geology in relation to specific mining or mineral-deposit problems; post-1971 maps are primarily black-and-white maps on various subjects such as environmental studies or wilderness mineral investigations.

Hydrologic Investigations Atlases are multicolored or black-andwhite maps on topographic or planimetric bases presenting a wide range of geohydrologic data of both regular and irregular areas; the principal scale is $1: 24,000$, and regional studies are at $1: 250,000$ scale or smaller.

\section{Catalogs}

Permanent catalogs, as well as some others, giving comprehensive listings of U.S. Geological Survey publications are available under the conditions indicated below from USGS Map Distribution, Box 25286, Building 810, Denver Federal Center, Denver, CO 80225. (See latest Price and Availability List.)

"Publications of the Geological Survey, 1879-1961" may be purchased by mail and over the counter in paperback book form and as a set microfiche.

"Publications of the Geological Survey, 1962-1970" may be purchased by mail and over the counter in paperback book form and as a set of microfiche.

"Publications of the U.S. Geological Survey, 1971-1981" may be purchased by mail and over the counter in paperback book form (two volumes, publications listing and index) and as a set of microfiche.

Supplements for 1982, 1983, 1984, 1985, 1986, and for subsequent years since the last permanent catalog may be purchased by mail and over the counter in paperback book form.

State catalogs, "List of U.S. Geological Survey Geologic and Water-Supply Reports and Maps For (State)," may be purchased by mail and over the counter in paperback booklet form only.

"Price and Availability List of U.S. Geological Survey Publications," issued annually, is available free of charge in paperback booklet form only.

Selected copies of a monthly catalog "New Publications of the U.S. Geological Survey" is available free of charge by mail or may be obtained over the counter in paperback booklet form only. Those wishing a free subscription to the monthly catalog "New Publications of the U.S. Geological Survey" should write to the U.S. Geological Survey, $582 \mathrm{Na}$ tional Center, Reston, VA 22092.

Note.-Prices of Government publications listed in older catalogs, announcements, and publications may be incorrect. Therefore, the prices charged may differ from the prices in catalogs, announcements, and publications. 


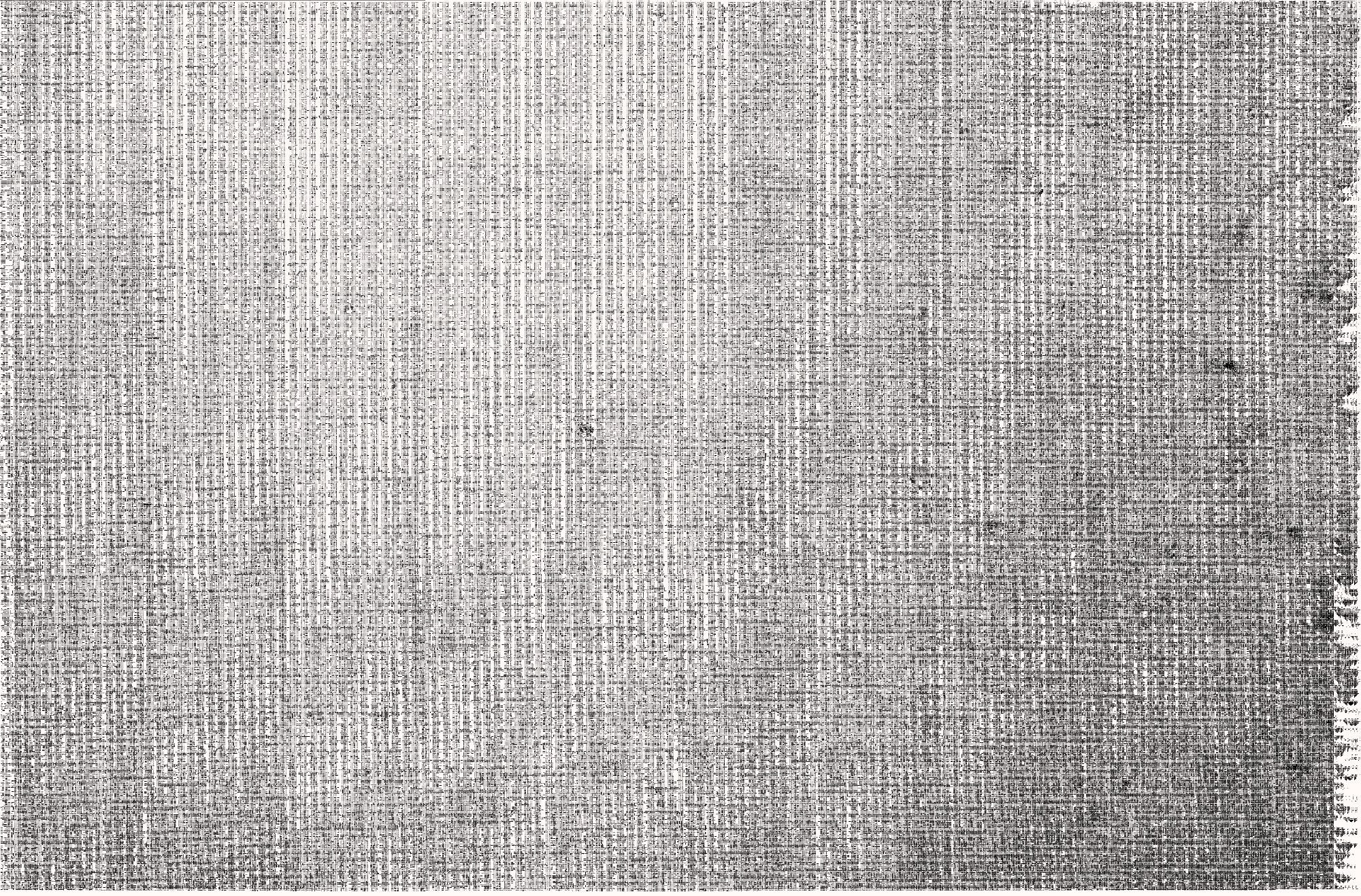

